Kaisa Häkkinen (Turku)

\title{
Matias Aleksanteri Castrén' ja Kalevalan ruotsinnos
}

Kun Elias Lönnrotin kokoama runoeepos, ns. Vanha Kalevala, ilmestyi vuonna 1835, se käänsi suomen kielen ja suomalaisen kulttuurin arvostuksen huimaan nousuun. Kalevala innosti myös maisteriopintojaan viimeistelevää, alkuaan pappisuralle aikonutta Matias Aleksanteri Castrénia suuntaamaan huomionsa suomen ja sen sukukielten tutkimukseen.

Koska alkuperäistä Kalevalaa pystyivät lukemaan vain muutamat harvat oppineiston edustajat, Suomalaisen Kirjallisuuden Seura julisti kilpailun runomuotoisen ruotsintai saksankielisen käännöksen aikaansaamiseksi. Tällaisia ei kuitenkaan ilmaantunut. Helsingin yliopiston suomen kielen lehtori Carl Niclas Keckman luennoi Kalevalasta ja laati siitä sanatarkan ruotsinnoksen, mutta ei runomittaista versiota. Muutaman vuoden odotuksen jälkeen Kalevalasta jo aiemmin kiinnostunut Castrén ryhtyi kääntämään eeposta. Suomalaisen Kirjallisuuden Seuran stipendiaattina hän keräsi kesällä 1839 taustatietoa ja uutta kansanperinneaineistoa Vienan Karjalassa.

Aktiivinen kääntäminen kesti noin kaksi vuotta. Käännöstyön ohella Castrén julkaisi dosentinväitöskirjan ja joitakin pienempiä tieteellisiä tutkimuksia. Kevätlukukaudella 1841 Castrén luennoi Helsingin yliopistossa Kalevalasta ja viimeisteli käännöstään. Se ilmestyi kesäkuussa 1841 ja sai hyvän vastaanoton. Esimerkiksi historiallis-vertailevan kielentutkimuksen kärkiedustajiin kuulunut Jacob Grimm perehtyi Kalevalaan ja luennoi siitä Berliinin tiedeakatemiassa Castrénin ruotsinnoksen perusteella.

Castrénin ruotsinnos avasi uusia mahdollisuuksia Kalevalaa koskevalle tieteelliselle keskustelulle, koska eepos oli nyt aiempaa merkittävästi laajempien piirien luettavissa. Tärkeä rooli tässä keskustelussa oli itse Castrénilla ja hänen Kalevala-tulkinnoillaan. Kalevalan käännöksen myötä Castrén sai pysyvän kansainvälisen maineen arvostettuna kansanperinteen ja mytologian asiantuntijana. Kirjoitus perustuu SuomalaisUgrilaisessa Seurassa 15.2.2019 pidettyyn esitelmään.

Elias Lönnrotin kokoaman Kalevalan ensimmäinen osa tuli painosta joulukuussa 1835, ja loppuosa ilmestyi alkuvuodesta 1836. Teoksesta tuli käännekohta sekä suomalaiskansallisen identiteetin rakentamisessa että maisteriopintojensa loppuvaiheessa kamppailevan Matias Aleksanteri Castrénin henkilökohtaisessa elämässä. Suomen kielellä ei tähän aikaan ollut mitään virallista asemaa suomalaisessa yhteiskunnassa, ja maan monikielisen sivistyneistön piirissä pidettiin hyvin todennäköisenä, ettei suomesta ikinä voisi tullakaan ruotsin veroista kulttuurikieltä. Kalevala oli kuitenkin vakuuttava todiste siitä, että oppimattomina ja yksinkertaisina pidetyt suomalaiset pystyivät omalla kielellään luomaan korkeatasoista kansankulttuuria.

1. Tässä artikkelissa käytetään yleisesti tunnettua suomalaistettua nimimuotoa Matias Aleksanteri sekaannusten välttämiseksi. Nimimuodolla Matthias Castrén viitataan Matias Aleksanterin vanhimpaan setään, Kemin kirkkoherraan, joka avusti ja tuki rahallisesti lahjakasta veljenpoikaansa. 
Kiinnostus suomen kieltä kohtaan alkoi nopeasti lisääntyä, ja varsinkin yliopistopiireissä esitettiin vaatimuksia ja ehdotuksia sekä kielen että sen aseman kehittämiseksi.

Vaikka Kalevala herätti innostusta ja ihastusta, sitä ei juuri luettu, sillä sen vaikeaselkoista runokieltä oli vaikea ymmärtää niidenkään, jotka puhuivat suomea äidinkielenään. Eräs Castrénin ja Kalevalan aikalaisista, Savo-karjalaisen osakunnan aktiivinen jäsen Karl Konstantin Tigerstedt on muistellut, että pohjalaiset Erik Alexander Ingman ja Matias Aleksanteri Castrén sekä savokarjalaiset Fabian Collan ja Herman Kellgren olivat niitä harvoja, jotka toden teolla ryhtyivät lukemaan Kalevalaa ja perehtymään sen aatemaailmaan. (Waris 1939: 116-117.)

Vasta Kalevalan ruotsinnos avasi eepoksen laajemmalle lukijakunnalle ja nosti samalla sen kääntäjän suuren yleisön tietoisuuteen. Ennen sitä Matias Aleksanteri Castrén oli ollut vain yksi uuttera tutkija monien kaltaistensa joukossa. Kalevalan käännöksen ilmestymisen jälkeen hän oli tunnettu ja arvostettu kansanrunouden ja mytologian asiantuntija. Kelvollisen runomittaisen käännöksen tekeminen ei kuitenkaan ollut helppo eikä aivan nopeakaan prosessi. Siihen tarvittiin sekä erityistä kielitaitoa että taustatietoja, joita oli hankittava monelta eri taholta.

\section{Castrén ja suomen kieli}

Matias Aleksanteri Castrén syntyi joulukuun 2. päivänä vuonna 1813 Lapin maakunnan lounaisessa osassa Tervolan pitäjässä, jossa hänen isänsä Christian Castrén työskenteli kappalaisena. Sekä isä Christian että äiti Susanna Sofia Fellman kuuluivat molemmat vanhoihin pohjalaisiin pappissukuihin. Vuonna 1821 Christian Castrén sai appensa, kirkkoherra Esaias Fellmanin kuoltua viran Rovaniemeltä. Hän kuoli kuitenkin jo vuonna 1825, mikä tiesi Susannalle ja hänen lapsilleen vaikeita aikoja.

Castrénin lapsuusaikana perhe asui suomenkielisillä seuduilla ja sen pääasiallinen kotikieli lienee ollut suomi, vaikka koulutetuissa piireissä oli tähän aikaan yleensä tapana käyttää ruotsia. Matias Aleksanterin varhaisesta kielitaidosta ei ole varsinaisia dokumentteja, mutta Anders Wilhelm Ingman on muistelmissaan kertonut, että kun Castrénin perheen nuoremmat pojat Aappa ja Iikka tulivat aikanaan kouluun, he eivät osanneet montakaan sanaa ruotsia (Pihlajamaa 2006: 19). Vaikka Matias Aleksanteri ei akateemiselle uralle lähdettyään pitänyt julkisia luentoja eikä kirjoittanut tieteellisiä tutkimuksia suomen kielellä, hän antoi kuitenkin suomen kielen tunteja yksityisopetuksena ja toimi monissa eri yhteyksissä suomen kielen asiantuntijana. Hänen muistiinpanoistaan ja hänen käyttämäänsä ruotsin kieltä koskevista arvosteluista (mm. Collan 1841) on pääteltävissä, ettei hän ainakaan tiedemiesuransa alkupuolella hallinnut ruotsia aivan syntyperäisen puhujan varmuudella.

Matias Aleksanteri sai alkeisopetusta kotonaan ensin vanhemmiltaan ja sitten Rovaniemelle muuton jälkeen palkatulta kotiopettajalta (Snellman 1870: 32-33). Christian Castrénin kuoltua Matias Aleksanteri ja hänen veljensä Esaias muuttivat Ouluun. Siellä asui heidän enonsa Abraham Fellman, varakas kauppias, joka 
tuki ahdinkoon joutunutta sisarensa perhettä monin tavoin. Myöhemmin myös äiti Susanna muutti nuorimpien lasten kanssa Ouluun. (Estlander 1928: 13-14.)

Henkistä tukea ja tieteellisiä herätteitä nuori Matias Aleksanteri sai erityisesti sedältään, Kemin arvostetulta kirkkoherralta Matthias Castrénilta. Setä oli aikoinaan ollut Henrik Gabriel Porthanin oppilaita Turun Akatemiassa, ja hänen tieteellisen kiinnostuksensa kohteita olivat historia ja kasvitiede. (Ruuth 1927: 387-388.)

Oulussa oli kohtuullisen hyvänä oppilaitoksena tunnettu triviaalikoulu. Koulussa opetuskieli oli ruotsi, mutta keskustelukielenä käytettiin yleisesti suomea (Snellman 1873: 20). Suomeksi saatettiin myös opetuksen yhteydessä lukea ja kirjoittaa runoja vanhan suomalaisen runomitan malliin (Snellman 1870: 35). Monet Pohjanmaan rannikon ruotsinkieliset perheet lähettivät tarkoituksella poikiaan Oulun kouluun, jotta nämä olisivat oppineet käytännön suomea. Koulun yhteydessä toimi epävirallinen "sanaseppojen seura", jossa harrastettiin suomen kieltä ja suhtauduttiin ylenkatseellisesti Helsingin herrojen suomeen. (A. W. Ingman 1873: 145-151.) Oulun koulusta olivat jo ennen Castrénia lähteneet maailmalle runoilijapiispa Frans Mikael Franzén ja hänen nuorempi velipuolensa Carl Niclas Keckman, josta tuli monessa mielessä tärkeä henkilö Matias Aleksanteri Castrénin elämänuralla. Myös Castrénin vanhempi ystävä ja yhteistyökumppani J. V. Snellman oli Oulun koulun kasvatteja, samoin Ingmanin veljekset Anders Wilhelm ja Erik Alexander.

\section{Ohdakkeisella opintiellä}

Vuonna 1830 Matias Aleksanteri Castrén aloitti opintonsa Helsingin Keisarillisessa Aleksanterin Yliopistossa. Alku ei ollut lupaava, vaikka hänet hyväksyttiinkin ylioppilaaksi erinomaisin arvosanoin. Hän tunsi itsensä yksinäiseksi eikä onnistunut löytämään uudelta paikkakunnalta ystäviä tai tukijoita. Häntä vaivasi ja hävetti myös köyhyytensä, jonka takia hänen oli elettävä äärimmäisen vaatimattomasti. Hänellä oli kyllä pohjoisessa varakkaita sukulaisia, joihin hän olisi hädän hetkellä voinut turvautua, mutta kun hän tiesi näiden joutuneen jo muutenkin auttelemaan monin tavoin hänen perhettään, hän mieluummin pysyi vaiti ja salasi ahdinkonsa. (Borg 1853: 8-9.)

Vanha Turun Akatemia oli vuoden 1827 tuhoisan tulipalon jälkeen siirretty autonomisen suuriruhtinaskunnan uuteen pääkaupunkiin Helsinkiin. Heti siirron jälkeen yliopistoon oli perustettu suomen kielen lehtorin virka. Se oli kautta aikojen ensimmäinen suomen kielen alaan kuuluva vakinainen virka yliopistotason oppilaitoksessa.

Suomen kielen lehtoriksi valittiin Oulussa syntynyt ja Turun Akatemiassa opiskellut Carl Niclas Keckman, joka pätevyytensä osoittamiseksi laati väitöskirjan suomen kielen refleksiivimuodoista. Lehtorin varsinaisena tehtävänä oli opettaa suomen kielen käytännöllistä taitoa papeiksi ja virkamiehiksi aikoville opiskelijoille, mutta Keckman asetti työlleen myös tieteellisiä tavoitteita. Ensimmäisen luentosarjansa syksyllä 1829 hän piti suomen kieliopista käyttäen opetuksensa perustana Reinhold von Beckerin vuonna 1824 julkaisemaa ruotsinkielistä kielioppia. Kangasniemellä syntynyt Becker halusi kehittää suomen kirjakieltä itämurteiden suuntaan ja toi 
kieliopissaan näkyviin murteiden välisiä eroja. Vuonna 1820 hän oli perustanut Turun Wiikko-Sanomat -nimisen sanomalehden, jossa hän ajoi itämurteiden asiaa.

Lukuvuonna 1833-1834 Keckman laajensi opetusohjelmaansa myös sukukieliä koskevaksi: hän opetti suomen, viron, saamen ja unkarin vertailevaa kielioppia. Käytännöllisten luentojensa tekstimateriaalina hän käytti mm. Johan Frosteruksen suosittua oppikirjaa Hyödyllinen huvitus luomisen töistä sekä Zachris Topelius vanhemman ja Elias Lönnrotin kansanrunojulkaisuja. (Keckmanin opetustyöstä laajemmin Pääkkönen 1994: 60-89.)

Syksyllä 1832 Keckman aloitti luennot Lönnrotin Kantele-vihkoista ja jatkoi niitä syyslukukauden 1835 loppuun asti. Keckman oli avustanut Lönnrotia Kalevalan toimittamisessa, ja nyt hän jo innokkaasti odotti eepoksen ilmestymistä voidakseen ottaa sen luentojensa aiheeksi. Kun Kalevalan ensimmäisen osan ilmestyminen kuitenkin lykkääntyi joulukuuhun asti, hän luennoi sen sijaan Zachris Topelius vanhemman viimeistä, postuumiksi jäänyttä runokokoelmaa (Topelius 1831), jonka toimittamiseen hän myös oli osallistunut. Castrén on todennäköisesti kuunnellut ainakin osaa Keckmanin luennoista.

Opintojensa alkuvaiheessa Castrén halusi keskittyä klassillisiin ja itämaisiin kieliin sekä filosofiaan. Sukunsa perinteitä noudatellen hänen tarkoituksenaan oli lähteä pappisuralle, mutta köyhyytensä takia hänen oli kuitenkin jo heti ensimmäisenä opiskeluvuotenaan lähdettävä kotiopettajaksi Uskelaan majuri Erik Johan Willebrandin perheeseen, jossa hän viipyi puolitoista vuotta. Elämä Uskelassa oli Castrénille monin tavoin hyvää aikaa. Hänen etevä oppilaansa Knut Felix Willebrand oli vain puolisen vuotta häntä itseään nuorempi. Ahkeran opiskelun lomassa metsästettiin, kalastettiin ja vietettiin viihtyisää seuraelämää. Willebrandista tuli Castrénin hyvä ystävä ja kirjeenvaihtotoveri. Aikanaan hänestä tuli lääketieteen professori ja lääkintöhallituksen ylijohtaja. Hän toimi sulhaspoikana, kun Castrén lokakuussa 1850 vihittiin Natalia Tengströmin kanssa, ja hän hoiti lääkärinä kuolemansairasta Castrénia tämän viimeisinä elinkuukausina keväällä 1852. Uskelassa Castrén tutustui myös kamarineuvos Johan Gabriel von Bonsdorffiin, joka oli naimisissa majuri Willebrandin tyttären kanssa. Myöhemmin Castrén sai asua usean lukukauden ajan Helsingissä von Bonsdorffin alivuokralaisena. (Estlander 1928: 19, 179; Havu 1945: 271.)

Castrén palasi yliopistoon syksyllä 1832 ja sai ensimmäiseksi lukuvuodeksi asunnon J. L. Runebergin alivuokralaisena. Suuressa talossa alivuokralaisia oli useita, ja yksi heistä oli Zachris Topelius nuorempi. Tässä ympäristössä Castrén pääsi suoraan pääkaupungin kulttuuripiirien ytimeen. Runeberg oli keskeinen henkilö Lauantaiseurassa, eräänlaisessa vapaamuotoisessa lukupiirissä, joka vuodesta 1830 alkaen oli kokoontunut vuorotellen kunkin jäsenensä kotona. Seuran perustajiin kuuluivat Runebergin lisäksi J. J. Nervander, veljekset A. A. ja G. Fr. Laurell, B. O. Lille ja J. J. Nordström, ja heti ensimmäisenä toimivuonna siihen liittyivät myös J. V. Snellman, Fr. Cygnaeus, L. I. Ahlstubbe, C. H. Ståhlberg ja M. J. Lindfors. Elias Lönnrot vieraili seurassa, milloin matkoiltaan ja muilta puuhiltaan ehti. (Havu 1945: 29.) 
Lauantaiseura oli monipuolinen kulttuuritoimija. Sen piirissä syntyi ajatus Suomalaisen Kirjallisuuden Seuran perustamisesta. Lauantaiseura perusti Helsinkiin edistyksellisen yksityisen oppikoulun, Helsingin lyseon, jossa myös Castrén sai toimia opettajana. Seuran miehet avustivat aktiivisesti kirjanpainaja J. C. Frenckellin perustamaa sanomalehteä nimeltä Helsingfors' Morgonblad. Runeberg työskenteli tämän lehden toimittajana siihen asti, kunnes hän muutti perheineen Porvooseen. Helsingfors' Morgonbladissa julkaistiin huomattavan runsaasti kaunokirjallisuutta ja kansanrunoutta käsitteleviä kirjoituksia. Myös Castrén avusti lehteä myöhemmin (Borg 1853: 19).

Suotuisasta ympäristöstä huolimatta Castrénin opiskelua hidastivat erilaiset vaikeudet, kuten heti alussa isorokko, joka piti hänet vuoteenomana kuuden viikon ajan. Tässä vaiheessa hän ei vielä herättänyt huomiota erinomaisilla tutkijankyvyillään, mutta ahkeraksi hänet tiedettiin. Joulunakin hän unohtui huonetoverinsa Johan Wegeliuksen kanssa opiskelemaan kreikkaa, vaikka vuokraisäntä oli kutsunut heidät mukaan yhteiselle joulupäivälliselle (Havu 1945: 95). Castrénin luonnetta on yleensä kuvattu ankaraksi, pidättyväiseksi, ylpeäksi, sulkeutuneeksi ja jopa synkäksi. Ainoastaan lähimpien ystäviensä kesken hän saattoi tuntea olonsa turvalliseksi ja vapautua. (Estlander 1928: 18; Havu mts. 61.)

Opiskelijapiireissä oli näihin aikoihin heräämässä aktiivinen harrastus suomen kieltä kohtaan. Näin oli laita etenkin Pohjalaisessa osakunnassa, johon Castrén kuului. Toukokuussa 1834 Castrénin ystävä Carl Robert Ehrström teki ehdotuksen, että kaikki osakuntalaiset suorittaisivat tutkinnon suomen kielessä ennen valmistumistaan. Castrén allekirjoitti toisena tämän lupauksen. Muistelmissaan Castrén on itse kertonut, että hän jo opiskeluaikanaan uurasti ahkerasti saavuttaakseen mahdollisimman täydelliset tiedot suomesta ja sen lähimmistä sukukielistä, minkä täytynee merkitä sitä, että hän mahdollisuuksien mukaan seurasi myös Keckmanin luentoja. Muuta opetusta suomen ja sen sukukielen alalta ei yliopistossa tähän aikaan ollut tarjolla.

Opiskeluun tuli kuitenkin katkos loppusyksystä 1834. Silloin Castrén ja viisi muuta pohjalaista, F. A. Ehrström, E. A. Ingman, Henrik Piponius, Lars Stenbäck ja J. J. Östring, erotettiin julkisesti yliopistosta puoleksi vuodeksi, koska he olivat osallistuneet teologisessa tiedekunnassa meneillään ollutta virantäyttöprosessia vastaan suunnattua mielenosoitusta valmistelevaan kokoukseen. Lisäksi länsisuomalainen G. A. Wallin erotettiin hiljaisesti, ja kapinamielen pesäpaikkana pidetty Pohjalainen osakunta jaettiin kahtia. (Rein 1928: 94-95.) Castrénille ylimääräisiä vaikeuksia aiheutti se, että hän menetti tapauksen takia luvassa olleen opiskelustipendin (Estlander 1928: 18). Hän vietti karkoitusajan muutamien kohtalotoveriensa kanssa Lohjalla opiskellen itämaisia kieliä (Borg 1853: 14).

Kevätlukukaudella 1836 Keckman alkoi luennoida Kalevalaa ja jatkoi kurssia maaliskuuhun 1838 asti. Helmikuussa 1836 Suomalaisen Kirjallisuuden Seura julisti kilpailun Kalevalan kääntämisestä. Se lupasi 500 ruplan palkinnon Kalevalan saksalaisesta tai ruotsalaisesta, runomittaisesta käännöksestä. Kilpailun määräajan päättymiseksi ilmoitettiin 1.12.1837. Yhtään ehdokasta ei kuitenkaan ilmaantunut, 
joten määräaikaa jatkettiin. Keckman oli tehnyt luentojaan varten suorasanaisen ruotsinnoksen koko Kalevalasta, mutta vaikka hän usein sepitteli kalevalamittaisia tervehdyksiä ja muita pieniä runoja esimerkiksi kirjeidensä höysteeksi, hän ei ryhtynyt pukemaan koko eeposta runomuotoon. Keckmanin kuoltua toukokuussa 1838 hänen tieteellinen jäämistönsä lahjoitettiin monessa eri erässä Suomalaisen Kirjallisuuden Seuralle. Aineistoon sisältyi käsikirjoituksia, joiden joukossa oli useiden suomenkielisten teosten sananmukaisia ruotsinnoksia, mm. Kalevalan suorasanainen käännös (SKS pöytäkirjat 17.10.1838, 16.3.1839; Årsberättelse 1839; Keckmanin käsikirjoituskokoelma Suomalaisen Kirjallisuuden Seuran kirjallisuusarkistossa).

Joitakin Kalevalan runomittaisia osia ilmestyi ruotsiksi muiden kääntäminä. Ensimmäisen käännöksen 11. runosta julkaisi Elias Lönnrot itse jo ennen Kalevalan ilmestymistä (Lönnrot 1835a), ja seuraavana vuonna E. A. Ingman julkaisi ruotsinkieliset käännökset 5. ja 29. runosta (Ingman 1836a, 1836b). Ingmanilla saattoi olla tarkoitus kääntää koko teos, mutta työ jäi kesken muiden tehtävien takia (Molnár 1981; Häkkinen 2019: 16-17). Myös Runeberg halusi kääntää Kalevalaa, mutta puutteellisen suomen kielen taitonsa takia hän ei ymmärtänyt alkutekstiä riittävän tarkasti. Niinpä hän pyysi C. N. Keckmania tekemään suorasanaisen ruotsinnoksen, jonka hän sitten muovasi runoksi (Runeberg 1836, 1837). Kalevala kiehtoi myös Ruotsiin muuttanutta Frans Mikael Franzénia, joka vuonna 1837 lähetti yksityiskirjeessä velipuolelleen Keckmanille oman, melko vapaamuotoisen käännöskatkelmansa, jota ei kuitenkaan julkaistu (Grotenfelt 1886).

\section{Työtehtävien ja jatko-opintojen ristipaineessa}

Kevätlukukauden 1836 lopulla Castrén suoritti kandidaatin tutkinnon hyvin arvosanoin. Mitään erityistä nerokkuutta hänen ei tässä vaiheessa vielä huomata osoittaneen. Hänet tunnettiin äärimmäisen ahkerana ja laajalti lukeneena, mutta ei sen enempää. (Borg 1853: 15.) Enolleen Abraham Fellmanille Castrén kirjoitti suunnittelevansa laajempia teologian opintoja papin uraa silmällä pitäen, mutta toisena vaihtoehtoehtona hänen mielessään oli apulaisrehtorin paikka Helsingin triviaalikoulussa (Borg 1853: 21). Lopullista päätöstä hän ei kuitenkaan vielä halunnut tehdä, ja seuraavien parin vuoden ajan hän elätti itsensä antamalla yksityisopetusta jopa 10 tuntia päivässä.

Opetustyönsä ohella Castrén työskenteli lehtimiehenä ja oli mukana yhtiössä, joka julkaisi Helsingfors' Morgonbladia. Castrénin kirjoittamaksi on arveltu anonyymia artikkelia "Några ord om Kalevala", joka ilmestyi Helsingfors' Morgonbladin numeroissa 95 ja 96 vuonna 1836 (esim. Anttila 1931: 239; Hautala 1954: 142), mutta Castrénin jäämistöjä ruotsinkieliseen sarjaan Nordiska resor och forskningar toimittanut C. G. Borg (1870: VI; vrt. Borg 1853: 16) on asiaa pitkään pohdittuaan monin eri perustein päätynyt siihen tulokseen, ettei kirjoitus ole Castrénin tekemä. Borgin perusteluihin voisi lisätä vielä sen faktan, että artikkeliin sisältyvät ruotsinkieliset runonäytteet eivät ole Castrénin Kalevala-käännöksen mukaisia vaan ne ovat identtisiä niiden katkelmien kanssa, jotka Snellmanin serkku, pohjalainen Henrik Piponius 
julkaisi Kalevalan sisältöä koskevassa selostuksessaan Spanska Fluganissa vuonna 1839. Tämän viimeksi mainitun osalta on pidetty selvänä, että myös selostukseen sisältyvät runokäännökset olivat Piponiuksen käsialaa lukuun ottamatta lopussa olevaa laajempaa näytettä, joka selväsanaisesti ilmoitettiin Runebergin tekemäksi, Helsingfors' Morgonbladissa jo aiemmin julkaistuksi käännökseksi. Joka tapauksessa keväällä 1837 Castrén julkaisi samassa lehdessä artikkelin, joka käsitteli suomalaista noituutta (Castrén 1837). Castrén puhui muinaissuomalaisesta mytologiasta ja taikuudesta myös Pohjalaisen osakunnan vuosijuhlassa (Castrén 1838). Näissä töissään Castrén otti aineistoa ja esimerkkejä Kalevalasta ikään kuin se olisi ollut alkuperäistä kansanperinnettä. Myöhemmin Castrén ilmaisikin selvästi käsityksenään, että hän piti Kalevalaa alusta loppuun aitona kansanrunoutena.

Opiskelun jatkaminen ei epävarmassa taloudellisessa tilanteessa ollut helppoa, mutta kieliopintojensa yhteydessä Castrén tuli lukeneeksi joitakin Rasmus Raskin teoksia, joista hän sai idean soveltaa Raskin metodeja suomensukuisiin kieliin (Borg 1853: 18-19). Lähteissä ei mainita, mistä kirjoista tarkalleen ottaen oli kysymys. Joka tapauksessa Castrén tunsi ainakin Raskin laatiman saamen kieliopin, jota hän hieman myöhemmin käytti lähteenä väitöskirjassaan. Tanskalainen Rask oli komparatiivisen kielitieteen ja kielitypologian uranuurtaja, joka tutki myös suomensukuisia kieliä (esim. Stipa 1990: 295-298). Aikanaan hän oli innostanut mm. Anders Johan Sjögreniä lähtemään tutkimusmatkoille suomensukuisten kansojen pariin ja auttanut häntä luomaan uraa Pietarissa (esim. Korhonen 1986: 40-41; Branch 2006: 344). Rask oli laajasti tutustunut eri kielikuntia edustaviin kieliin, ja hänen kehittämäänsä metodia noudattaen oli mahdollista kirjoittaa kielioppeja sellaisistakin kielistä, joita ei itse osannut. Olennaista oli tehdä havaintoja ja kerätä uutta tietoa kentällä aidossa ympäristössä käyttäen apuna syntyperäisiä kielenoppaita. Castrénissa heräsi halu seurata Raskin ja Sjögrenin esimerkkiä ja lähteä tutkimusmatkoille sukukansojen pariin keräämään aineistoa, mutta köyhälle opiskelijalle se ei käytännössä ollut mahdollista ilman ulkopuolista tukea.

Kesäksi 1838 Castrén pääsi yllättäen Lappiin, kun hänen ystävänsä Carl Robert Ehrström kutsui hänet matkaseurakseen. Ehrström oli saanut paikan Tornion piirilääkärinä ja halusi tutustua laajaan tehtäväkenttäänsä tutussa seurassa. Castrénin lisäksi seurueeseen kuuluivat Zachris Topelius nuoremman entinen kotiopettaja, kasvi- ja eläintieteilijä F. J. Blank, josta myöhemmin tuli Uudenkaupungin kaupunginlääkäri, sekä Oulun triviaalikoulun kasvatti Josef Wilhelm Durchmann, joka oli juuri saanut työpaikan Inarin kappalaisena. Pikaisten matkavalmistelujen yhteydessä Castrén valtuutti Lauantaiseurasta tutun Lars Isak Ahlstubben jättämään puolestaan hakupaperit yliopistoon. Lehtori Keckman oli juuri kuollut, ja hänen paikkansa odotettiin tulevan haettavaksi matkan aikana.

Castrén ei vielä ensimmäisellä Lapin-matkallaan pystynyt järjestelmällisesti keräämään merkittäviä tutkimusaineistoja, mutta hän sai monia kauaskantoisia ideoita ja hyödyllisiä kokemuksia. Muonioniskan kirkolla hän tutustui saamelaiseen Isakssoniin, jonka norjalainen kielentutkija ja pappi N. V. Stockfleth oli lähettänyt sinne opiskelemaan suomea. Castrén oppi häneltä saamen kielen alkeet ja opetti 
vastineeksi hänelle suomea niiden kahden viikon aikana, joina matkalaiset viipyivät paikkakunnalla. Muonioniskalta Ehrström palasi Tornioon, mutta muut jatkoivat kohti Utsjokea. Venematkalla Enontekiön Peltovuomasta eteenpäin opas Erik Peltovuoma intoutui viihdyttämään matkalaisia laulamalla mm. Väinämöisen matkasta Pohjolaan kosimaan Pohjan tytärtä. Tämä herätti Castrénissa ihmetystä ja samalla ajatuksen, että Kalevalan mytologiaa tutkittaessa myös saamelaisella perinteellä olisi tärkeä rooli. Toinen opas Jessiö taas osoittautui melkoiseksi šamaaniksi. Castrén pani muistiin paikallistarinoita, runoja ja kertomuksia. Monenlaisista vaikeuksista huolimatta hän huomasi selviytyvänsä kohtuullisen hyvin tutkimusmatkailijan roolissa. Jälkeenpäin hän kirjoitti ystävälleen Ehrströmille, että matkan jälkeen elämä pölyisessä työhuoneessa tuntui ikävältä, yksitoikkoiselta ja lapselliselta verrattuna vaeltamiseen Pohjolan korkeilla, rakkailla tuntureilla (Castrén 1839a: 105).

Kun Castrén palasi syyskuussa 1838 Helsinkiin, hän sai kuulla asiamiehensä olleen huolimaton. "Vanha Stubbe" oli laiminlyönyt määräajan, hakupaperit olivat myöhästyneet, ja lehtori paikka oli nyt menossa Carl Axel Gottlundille. Toinenkin tilaisuus näytti menevän sivu suun. A. J. Sjögren oli vieraillut Helsingissä etsimässä sopivaa ehdokasta Pietarin Tiedeakatemian valmistelemaan monitieteiseen retkikuntaan, jonka oli määrä tehdä tutkimusmatka Siperiaan. Sjögren ei itse voinut osallistua matkalle heikentyneen terveytensä takia. Sekä Castrén että Wallin kirjoittivat Sjögrenille ja ilmoittautuivat halukkaiksi. Vaaka kallistui Castrénin eduksi, sillä toisin kuin Ahvenanmaalla syntynyt Wallin hän oli tottunut Pohjolan ankariin oloihin, ja lisäksi hänet tunnettiin hyvänä metsästäjänä. Ystävälleen Ehrströmille Castrén kirjoitti innoissaan, ettei maailmassa olisi mitään sen suurempaa onnea kuin että hän saisi Sjögrenin sijaisena osallistua Siperian matkaan (Castrén 1839a: 106). Suunnitelman toteutuminen näytti kuitenkin lykkääntyvän kerta toisensa jälkeen hamaan tulevaisuuteen, joten Castrénin täytyi odotellessaan tarttua muihin tehtäviin.

\section{Kalevalan ruotsintaminen alkaa}

Castrén oli vuonna 1837 liittynyt jäseneksi Suomalaisen Kirjallisuuden Seuraan, ja seuraavana vuonna hänet valittiin jäseneksi tutkijakuntaan, jonka tehtävänä oli arvioida julkaistavaksi tarjottuja kirjoituksia ja antaa niistä lausuntonsa. Näin hän oli aitiopaikalla toteamassa, että Kalevalan kääntämistä koskeva palkintokilpailu näytti jäävän tuloksettomaksi siitä huolimatta, että määräaikaa oli jatkettu. Seuran hallussa oleva Keckmanin suorasanainen käännös, jonka Franzén oli luovuttanut syksyllä 1838 (Pöytäkirja 17.10.1838), ei täyttänyt runomuotoisuuden kriteeriä, joka kilpailutyölle oli asetettu, eikä se muutenkaan ollut niin viimeistelty, että se olisi sellaisenaan ollut julkaisemisen arvoinen, vaikka Franzén oli tätä mahdollisuutta esittänyt luovutuksen yhteydessä.

Irma Sulkunen (2004: 81-83) on Suomalaisen Kirjallisuuden Seuran historiaa käsittelevässä teoksessaan epäillyt, että Castrén olisi kaikessa hiljaisuudessa ominut Keckmanin käännöksen ja muun Kalevala-aineiston ja julkaissut käännöksen 
omanaan, mutta Keckmanin käsikirjoituksen ja Castrénin ruotsinnoksen vertailu osoittaa, että tällainen epäily on aiheeton. Kysymys on selvästi kahdesta eri käännöksestä. Castrénin ruotsinnos ei myöskään valmistunut epäilyttävän nopeasti niin kuin Sulkunen arviossaan antaa ymmärtää. Käännösten suhteisiin palataan jäljempänä.

Mahdollisesti juuri liittyessään kiinteämmin Suomalaisen Kirjallisuuden Seuran toimijakaartiin Castrén alkoi suunnitella Kalevalan ruotsintamista, vaikka ei heti tarttunutkaan tositoimiin. Käännöksestä luvattu palkintokin saattoi houkutella jatkuvassa rahapulassa kamppailevaa Castrénia. Matkakertomuksessaan Castrén on todennut, että käännösasia oli ollut hänen mielessään jo ennen kuin hän lähti aineistonkeruumatkalle Karjalan runomaille kesällä 1839. On selvää, että alkuun pääsyä hidasti eepoksen outo sanasto. Tämä on pääteltävissä myös Castrénin Kalevalaa koskevista muistiinpanoista: ensimmäisessä runosäkeiden järjestyksen mukaisessa sanalistassa (KK Coll. 539:1 D2: 361-384; Fennica 2019: 423-451) on suuri osa ongelmallisiksi katsottuja sanoja Kalevalan ensimmäisen osan (runot 1-16) runoissa jäänyt ilman selitystä. Vastaavat vaikeudet olivat olleet tuttuja myös Kalevalasta luennoineelle Keckmanille, jonka oli tämän tästä kysyttävä selityksiä Lönnrotilta, joka hänkään ei aina pystynyt antamaan varmaa vastausta. Keckmanin ja Lönnrotin välisestä kirjeenvaihdosta käy ilmi, että sananselitysten kysely jatkui aina Keckmanin kuolemaan asti. Kun sanaston selvittelyssä tarvittavaa käsikirjallisuutta ei ollut riittävästi tarjolla, lisää selityksiä ja taustatietoa oli päästävä keräämään kentältä, runonlaulajilta itseltään.

Kesällä 1839 toukokuusta syyskuulle Castrén sai mahdollisuuden kerätä kansanperinnettä Savossa ja Karjalassa Suomalaisen Kirjallisuuden Seuran stipendiaattina. Matkalla mukana olivat tunnetun kansallisen kulttuurivaikuttajan, professori Johan Jakob Tengströmin 16-vuotias poika Robert ja tämän hieman vanhempi serkku Johan Martin Tengström, joka oli suuntautumassa luonnontieteiden alalle. Seuran pöytäkirjan mukaan Castrénin tehtävänä oli kerätä "mytologislaatuisia selityksiä Kalevalaan sekä historiallisia perimätietoja ja satuja", mutta mitään mainintaa Kalevalan kääntämisestä ei tässä yhteydessä ole (Pöytäkirjat 1.5.1839 ja 6.11.1839). Lönnrotin jälkiä seuraten Castrén kävi tunnetuissa runokylissä, mm. Miinoassa, Latvajärvellä, Vuonnisessa ja Uhtualla (kartta matkareitistä teoksen Fennica 2019 etukannen sisäsisäsivulla). Hän tapasi Arhippa Perttusen, Vaassila Kieleväisen ja monia muitakin laulajia. Kaikkea kuulemaansa hän ei välittänyt merkitä muistiin, koska monet runot muistuttivat hänen mielestään liikaa jo aiemmin koottuja ja julkaistuja lauluja. ${ }^{2}$ Seuralle antamassaan matkaraportissa Castrén totesi, että hänen keskeinen tavoitteensa oli hankkia lisätietoja suomalaisesta mytologiasta (Castrén 1840a). Samalla matkalla, jolta hän palasi Oulun ja Pohjanmaan kautta, hän tutki myös arkeologisia muinaisjäännöksiä.

Kotiin palattuaan Castrén ei heti uppoutunut Kalevalan kääntämiseen. Hän oli oivaltanut, että tuntematon maisteri, jolla ei ollut mitään varsinaista näyttöä suomensukuisten kielten tutkimuksesta, ei välttämättä vaikuttanut varteenotettavalta

2. Castrénin keräämää runoaineistoa löytyy helposti nimihaun perusteella SKVR-tietokannasta. 
apurahanhakijalta Pietarin akateemikkojen ja professorien silmissä. Tieteellisen uskottavuutensa lisäämiseksi Castrén laati latinankielisen väitöskirjan, jossa hän vertaili suomen, viron ja saamen nominien taivutusta (Castrén 1839b). Unkaria lukuun ottamatta hän vertaili siis samoja kieliä, joita myös Keckman oli vertaillut luennoissaan, mutta uudelta pohjalta, seuraten indoeurooppalaisen kielentutkimuksen piirissä kehitettyä historiallis-vertailevaa metodia. Teoreettisina esikuvinaan Castrén mainitsi Rasmus Raskin, Franz Boppin ja Jacob Grimmin. Useita kertoja hän viittasi myös saksalaisen tutkijan Karl Ferdinand Beckerin yleiskielitieteelliseen teokseen Organism der Sprache, vaikka ei ollutkaan Beckerin kanssa samaa mieltä kieliopillisten kategorioiden keskinäisistä suhteista. Castrénilla tutkittavia kieliä koskeva lähdepohja oli paljon laajempi ja tuoreempi kuin Keckmanilla, mukana olivat mm. Sjögrenin ja Stockflethin tutkimukset. Lisäksi Castrén otti Raskin tapaan vertailukohdaksi muiden kielikuntien kieliä, etenkin indoeurooppalaisia ja turkkilaisia kieliä. Esimerkiksi saamen ja suomen äännevaihteluja hän vertasi islannin vaihteluihin. Esityksen aineisto oli pääosin koottu muiden tutkijoiden julkaisuista, mutta niiden lisäksi Castrén esitti myös jonkin verran omia havaintojaan.

Ystävälleen Ehrströmille Castrén lähetti helmikuun 1840 alussa väitöskirjansa todeten, että se oli hänen Lapin-matkansa hedelmä. Samalla hän perusteli, että oli hyvä laatia kirja tai kaksi, joilla voisi sopivasti "nykäistä" pietarilaisia. Toisena kirjana hän mainitsi Kalevalan ruotsinnoksen, jonka hän suunnitteli antavansa painettavaksi viimeistään syksyllä 1840. (Castrén 1840 b: 108.)

Kysymys työstä ja toimeentulosta ei vielä väitöskirjan myötä ratkennut. Tammikuussa 1840 Castrén sai nimityksen suomen ja skandinaavisten muinaiskielten dosentiksi Keisarilliseen Aleksanterin Yliopistoon. Dosentuuri merkitsi kuitenkin vain lupaa pitää julkisia luentoja, mitään varsinaisia palkkaetuja se ei tuonut mukanaan. Niinpä Castrén ei kiirehtinyt aloittamaan luentoja, joista palkkiona olisi ollut lähinnä mainetta ja kunniaa. Hänen oli pakko elättää itseään tilapäisillä palkkatöillä.

Yhtenä mahdollisena työpaikkana Castrén kaavaili Suomalaisen Kirjallisuuden Seuran isännöimää sanakirjahanketta. Gustaf Renvallin vuonna 1826 valmistunut Suomalainen Sana-Kirja oli loppuunmyyty, ja lisäksi se oli ehtinyt jo pahasti vanhentua. C. N. Keckman oli lehtorin toimensa ohella kartuttanut sen aineistoa parhaansa mukaan, jotta hän olisi voinut julkaista uuden, laajemman ja ajantasaisemman sanakirjan. Keväällä 1838 Suomalaisen Kirjallisuuden Seura olikin päättänyt kiinnittää Keckmanin ja pari apulaista vakituiseen sanakirjatyöhön. Suunnitelma kuitenkin kaatui, kun Keckman kuoli pian päätöksen jälkeen. (Anttila 1935: 4.)

Sanakirjatyötä päätettiin jatkaa apuvoimin. Aluksi ajateltiin, että riittäisi, kun Keckmanin aineistot järjestettäisiin Renvallin sanakirjan mukaiseen järjestykseen ja kirjoitettaisiin puhtaaksi. Työhön palkattiin ensin Carl Jacob Keckman ja sitten Otto Tandefelt. (SKS pöytäkirjat 17.10.1838, 16.3.1839, 6.11.1839.) Muiden aineistojen kopiointiin osallistui mahdollisesti muitakin. Seuran arkistossa oleva Keckmanin kielioppiluentojen puhtaaksi kirjoitettu kopio näyttäisi olevan Castrénin käsialaa, ja sitä koristaa samanlainen monimutkainen vinjetti, jonka Castrén piirsi myös oman kielioppikäsikirjoituksensa loppuun (kuva Fennica 2019: 580). Käsikirjoitukseen on 
liitetty maininta, että se on tullut seuran haltuun Carl Gustaf Borgin paperien myötä, ei siis Keckmanin perikunnalta. Borgin tehtävänä oli Castrénin kuoleman jälkeen selvitellä tämän kirjallista jäämistöä ja huolehtia erityisesti yleistajuisesta aineistosta sekä niistä suomeen ja saameen liittyvistä käsikirjoituksista, joita ei missään vaiheessa lähetetty Pietariin Anton Schiefnerin toimitettaviksi.

Keckmanin sanamuistiinpanoja kopioitaessa ja järjestettäessä kävi pian selväksi, että laajuudestaan huolimatta aineisto oli edelleen puutteellinen. Kirjakielen sanasto karttui koko ajan nopeata vauhtia, ja myös murresanastoa haluttiin koota lisää. Aineiston täydentäminen ja sanakirjatyön jatkaminen uskottiin Elias Lönnrotin vastuulle. Joka tapauksessa tähän työhön tarvittiin avustajia, ja yksi sopiva kandidaatti olisi omasta mielestään saattanut olla Castrén. Lönnrotilla oli kuitenkin monta rautaa tulessa, eikä hän tässä vaiheessa vielä halunnut sitoutua täysipäiväisesti vuosien mittaiseen sanakirjaprojektiin, vaikka hän periaatteessa suhtautuikin hankkeeseen myönteisesti. Aktiivisen toimitustyön käynnistyminen lykkääntyi toistaiseksi. Toisena vaihtoehtona Castrén pohti opettajan uraa Helsingin triviaalikoulussa, mutta pysyvää ratkaisua ei sillä erää löytynyt. (Estlander 1928: 42.)

Ilmeisesti vasta väitöskirjansa valmistumisen jälkeen Castrén alkoi tosissaan kääntää Kalevalaa. Helmikuun 5. päivänä 1840 merkittiin toiveikkaasti Suomalaisen Kirjallisuuden Seuran pöytäkirjaan, että kysymys Kalevalan ruotsintamisesta saattaisi lopultakin ratketa Castrénin ansiosta. Kuukauden kuluttua Castrén toimittikin neljän ensimmäisen runon ruotsinnokset tutkijakunnan arvioitaviksi. Maaliskuussa 1840 Seura päätti, ettei Kalevalan käännöskilpailua enää jatkettaisi vaan jäätäisiin odottamaan Castrénin käännöstä. Vuosikertomuksessaan 16.3.1842 seura summasi prosessia, että aina kevääseen 1840 asti oli odotettu käännöskilpailun tuloksia, mutta kun kelvollisia ehdokkaita ei ilmaantunut yhtäkään, valittiin suorempi toimintatapa ja kehotettiin Castrénia suorittamaan käännöstyö. Työn valmistuttua palkkioksi annettiin ne 500 ruplaa, jotka oli varattu käännöskilpailun palkinnoksi. (Helsingfors' Morgonblad 26.3.1842.)

Maaliskuussa 1840 Castrén joutui yllättäen runonlaulajan rooliin, kun hän pohjalaisten edustajana osallistui Savo-karjalaisen osakunnan vuosijuhlaan. Kunniavieraana oli Elias Lönnrot, jonka kokoaman Kantelettaren ensimmäinen kirja oli juuri ilmestymässä painosta. Juhlapuhujana oli Fabian Collan, joka käsitteli laajasti Kantelettaren sisältöä ja merkitystä. Lönnrot ja Castrén istutettiin keskelle salia laulamaan vanhoja runoja, ja ylioppilaat kuuntelivat innoissaan kansanrunojen yksivakaista poljentoa. Suosionosoitusten raikuessa molemmat laulajat nostettiin ilmaan esityksen päätteeksi. (Waris 1939: 119.)

Huhtikuussa 1840 seura määräsi kirjastonhoitajansa Gabriel Reinin yhdessä Lönnrotin, Castrénin ja Ståhlbergin kanssa järjestämään ja luetteloimaan uutta erää Keckmanin jälkeenjääneitä käsikirjoituksia. Keckmanin aineistojen tutkiminen hyödytti varsinkin Castrénia henkilökohtaisesti, koska joukossa oli runsaasti Kalevalaa koskevaa materiaalia, mm. luentoja varten tehtyjä muistiinpanoja, pääosin suorasanainen ruotsinnos ja suuret määrät sananselityksiä, joista monet olivat alkuaan peräisin Lönnrotilta (Keckmanin käsikirjoituskokoelma A 1404, A 1423; Lönnrotiana 
334). Lisäksi sieltä löytyi aiemmin ilmestyneiden kansanrunojulkaisujen ruotsinnoksia ja sanastopoimintoja (A 1407, A 1416, A1421; Lönnrotiana 31). Näistä merkittävä osa, mm. Renvallin sanakirja ja kokonaisten kansanrunousteosten käännökset, oli tullut seuran arkistoon jo Franzénin lahjoittaman ensimmäisen aineistoerän mukana syksyllä 1838. Aineistoa oli jo muiltakin kerääjiltä. Esimerkiksi kansanrunojen sanaston selityksiä oli kerännyt ylioppilas J. F. Cajan, joka oli Lönnrotin matkakumppanina vaeltanut Savossa ja Vienan Karjalassa vuonna 1836 (Anttila 1931: 317, 335). Castrénin omissa Kalevala-muistiinpanoissa on runsaasti viittauksia Lönnrotiin, Keckmaniin, Renvallin sanakirjaan ja muihinkin lähteisiin (Fennica 2019: 435 alk.).

Kalevalan kääntäminen eteni nyt ilmeisesti hyvin, sillä kesällä 1840 Castrén uskaltautui jo ottamaan vastaan Kalevalan tilauksia (esim. Helsingfors' Morgonblad 18.6.1840, Ảbo Tidningar 4.7.1840). Lisäksi hän julkaisi käännösnäytteenä pääosan runosta 31 (Helsingfors' Morgonblad 54/1840). Ilmoituksen mukaan käännös valmistuisi tulevana syksynä sillä edellytyksellä, että tilaajia ilmaantuisi riittävästi. Helsingfors' Morgonbladin kulttuurihistoriallisessa vuosikatsauksessa 1840 todettiin, että käännöstä oli alettu painaa vuoden 1840 puolella, ja ensimmäisen osan odotettiin ilmestyvän alkuvuodesta 1841 (Helsingfors' Morgonblad 18.1.1841). Aikataulu kuitenkin viivästyi, sillä Castrén teki samalla paljon muutakin kuin Kalevalan käännöstä, ja koko teoksen ilmestyminen lykkääntyi kesäkuuhun 1841.

Kesällä 1840 Castrén piti hieman taukoa kirjallisista töistään ja teki matkan sukulaistensa luo Pohjanmaalle (Estlander 1928: 42-43). Hän vieraili setänsä, kirkkoherra Matthias Castrénin luona Kemin pappilassa, ja sieltä lähtiessään 31.8.1840 hän kirjoitti omaa elämäntehtäväänsä ja yksinäistä vaellustaan kuvaavan runon serkulleen Emmalle, joka toimi leskeksi jääneen setänsä taloudenhoitajana. Nimen asemesta allekirjoituksena oli "Den enslige vandraren".

Torr och ödslig är den bana,

Som mig leder fram till målet;

O hur ljuft då är att finna

Någon källa under färden,

Ur hvars rena, klara bölja

Vandraren sig vederqvicker.

När han så från källan nödgas

Draga sig till ödemarken,

För att nya öden möta,

Städse saknar han den källan,

Fast han icke mer kan hoppas

Att densamma återfinna.

O farväl, farväl då, Emma!

3. Runo on ensimmäisen kerran julkaistu 31.10.1876 Hufvudstadsbladetissa, jonne sen oli lähettänyt tuntemattomana pysytellyt henkilö Pohjanmaalta. Toisin kuin Estlanderin kirjoittamassa elämäkerrassa, lehdessä arvellaan, että runo olisi kirjoitettu jo Castrénin ensimmäisellä Lapin-matkalla 1838. 
Sänd dock någon gång från fjerran

Vänlig helsning hän till vandrarn,

Som bland mödor, faror, plågor

Söker hjertats sorger döfva.

O hvem vet, om det ej kunde

Lindra sorgerna och qvalen,

Jaga bort de dunkla minnen,

Frid och fröjd i hjertat gjuta,

Skänka mod och kraft åt mannen,

Att bekämpa ödets nycker

Och med glädje lifvet offra

Uti striden för det Sanna.

Emma oli Matthias Castrénin nuoremman velipuolen ja Christian Castrénin veljen Zacharias Castrénin tytär. Emman kirjeistä käy ilmi, että nuorten välillä oli muutakin kuin sukurakkautta. Runoa lukuun ottamatta Matias Aleksanterin lähettämät kirjeet ovat kuitenkin kadonneet, sillä Emma ilmeisesti tuhosi ne mennessään vuonna 1845, setänsä kuoleman jälkeen, naimisiin Johan Gabriel Laguksen kanssa. Runo on kirjoitettu samaan kalevalaistyyppiseen runomittaan, jota Castrén käytti Kalevalan ruotsinnoksessa.

Syksyllä Castrén palasi työn ääreen, mutta uusia tehtäviä siunaantui koko ajan. Hänestä tuli Pohjoispohjalaisen osakunnan kuraattori. Hän seurusteli yhä ahkerammin J. J. Tengströmin kulttuuripiirissä, jossa isänmaalliset harrastukset olivat keskeisellä sijalla. Hän alkoi antaa suomen kielen yksityisopetusta Jakov Grotille, josta oli tulossa Helsingin yliopiston ensimmäinen venäjän kielen professori. Hän lupautui kirjoittamaan selostuksen (Castrén 1842) Lapin-matkastaan kalenteriin, jota Grot oli toimittamassa yliopiston 200-vuotisjuhlan kunniaksi. Castrén lähti myös mukaan toimittamaan Suomi-nimistä aikakauskirjaa, jonka kolme piirilääkäriä, Kajaanin Elias Lönnrot, Oulun Gustaf Asp ja Raahen J. F. Ticklén, olivat intoutuneet perustamaan syyskuussa 1840 kokoontuessaan juhlimaan keisari Aleksanterin nimipäivää pohjoissavolaiseen Nissilän kestikievariin. Virallinen ilmoitus Suomi-kirjan perustamisesta julkaistiin joulukuussa (Finlands Allmänna Tidning 9.12.1840), ja ilmoituksen allekirjoittajina Aspin, Lönnrotin ja Ticklenin lisäksi olivat Castrén, Lönnrot, Frans Joh. Rabbe, Gabriel Rein, C. H. Ståhlberg ja J. E. A. Wirzén. Castrén kirjoitti ruotsinkieliset artikkelit lappi-sanan merkityksestä (Castrén 1841a) ja eräistä suomen kielen äänteistä (Castrén 1841b) Suomi-kirjan ensimmäiseen niteeseen. Marraskuun 1840 alusta lähtien Castrén alkoi toimia Suomalaisen Kirjallisuuden Seuran sihteerinä, joskin entinen sihteeri Carl Henrik Ståhlberg tarttui välillä kynään käsiteltäessä Castrénia koskevia asioita. 


\section{Luennot Kalevalasta}

Keväällä $1841^{4}$ Castrén piti luentoja Kalevalasta ja viimeisteli samalla käännöstään. Sen taustaksi hän oli laatinut tiiviitä muistiinpanoja eri näkökulmista: erisnimistä, sanastosta ja kieliopillisista erikoispiirteistä (Fennica 2019: 396-457, 480-657). Muistiinpanoissa on suuri määrä viittauksia eri lähteisiin, mm. Renvallin sanakirjaan sekä Topelius vanhemman ja Elias Lönnrotin julkaisemiin runovihkoihin (Topelius 1822, 1823, 1826, 1829, 1831; Lönnrot 1829-1831). Osassa viittauksista on mainittu pelkästään henkilön nimi tai nimilyhenne, useimmiten Lönnrot tai Keckman, joskus myös sanomalehti tai muu julkaisu, jossa kyseistä yksityiskohtaa oli käsitelty. Pelkät nimet tai lyhenteet saattavat viitata myös suullisiin tiedonantoihin tai siihen eri lähteistä koottuun arkistomateriaaliin, jota Keckmanin jäljiltä oli runsaasti Suomalaisen Kirjallisuuden Seuran arkistossa, osittain alkuperäisenä, osittain puhtaaksi kirjoitettuna.

Castrén aloitti luentosarjan yleisluontoisella johdannolla, jossa hän kansallisromanttisesta näkökulmasta hahmotteli Suomen kansan menneisyyttä ja tulevaisuutta (Castrén 1870). Castrén totesi, että ruotsalaiset olivat kyllä tutustuttaneet suomalaiset kristinuskoon ja eurooppalaiseen kulttuuriin, mutta eivät olleet huolehtineet suomalaisen kansallishengen kehittämisestä. Päinvastoin he olivat levittäneet kansan piiriin käsitystä, että kaikki ulkomaalainen oli hienompaa ja parempaa kuin suomalainen raakuus ja sivistymättömyys. Kuitenkin jokainen, joka oli lukenut Runebergin Hirvenhiihtäjät, ymmärsi varmasti, millaista voimaa ja suuruutta piili suomalaisessa talonpojassa ja Suomen kansassa. Castrén siteerasi myös Rasmus Raskia, joka oli ylistänyt suomen kielen soinnukkuutta, rikkautta ja kieliopillista säännönmukaisuutta. Lopuksi hän totesi, että suomalaiset kansanrunot olivat Homerokseen, Ossianin lauluihin ja Edda-runoihin verrattava aarre.

Johdantoluennon jälkeen Castrén kävi yksityiskohtaisesti Kalevalan tekstiä läpi. Ilmeisesti hän luki aina ensin runokatkelman ja esitti sitten oman käännöksensä sekä katkelmaa koskevat huomautuksensa ja selityksensä etukäteen valmistettujen kommenttikäsikirjoitusten mukaan. Castrénin luentojen ja osakunnassa pitämien puheiden innokkaaseen kuulijakuntaan kuuluivat Robert Tengströmin ja hänen kuopiolaissyntyisen ystävänsä Herman Kellgrenin ohella Anders Wilhelm Ingman, Fabian Collan, J. R. Bergstadi, J. O. I. Rancken, William Nylander, Karl Konstantin Tigerstedt ja monet muut. A. W. Ingman on muistelmissaan kutsunut 1840-luvun ensimmäisiä vuosia "Castrénin ajaksi” (A. W. Ingman 1871: 223). Tätä kesti vuoden 1842 loppuun asti, jolloin Snellman palasi Ruotsista Suomeen ja otti näyttämön haltuunsa.

Castrén luennoi Kalevalaa vain yhden lukukauden ajan, ja tästä syystä hän ehti käsitellä eepoksesta vain alkuosan. Osanaikaa hän oli sairaana. Ystävälleen Ehrstömille hän kirjoitti kesäkuussa 1841, että hän oli useiden viikkojen ajan elää kituuttanut kuin varjo vatsakuumeen kourissa, ja koko ajan uudet matkasuunnitelmat pyörivät

4. Eräistä lähteistä saa sen virheellisen käsityksen, että luennot olisi pidetty jo kevätlukukaudella 1840 (esim. Joki 1953: 7-8; Sulkunen 2004: 82). 
hänen mielessään (Castrén 1841c: 108-198). Hermann Kellgren on todennut kirjeessään Robert Tengströmille, että Castrén pääsi vain neljännen runon loppuun asti (G. Castrén 1945: 201), ja samaan viittaa myös luennoilta säilyneen käsikirjoitusaineiston jaksotus. Tahti oli joka tapauksessa ripeämpi kuin Keckmanilla, joka oli viiden lukukauden aikana saanut käsitellyksi vajaat seitsemän runoa (Pääkkönen 2005: 84 ).

\section{Käännöksen julkaiseminen}

Castrén oli kääntänyt Kalevalaa vähitellen, ja kuten edellä on jo todettu, aikaa kului enemmän kuin alun perin oli suunniteltu. Käännöstä tarkastamaan nimetyllä valiokunnalla ei ollut mahdollisuutta arvioida teosta kokonaisuutena, kun runoja tuli tarkastettavaksi pienissä erissä ja osa painettiin jo ennen kokonaisuuden valmistumista. Valiokunnalla oli jonkin verran huomautettavaa käännöksen yksityiskohdista ja ruotsinkielisestä asusta, ja näistä luvattiin ilmoittaa tekijälle henkilökohtaisesti. Alkuperäinen Kalevala oli ilmestynyt seuran omassa julkaisusarjassa, mutta sen käännöstä ei vähävarainen seura edes suunnitellut kustantavansa kokonaan. Näin ollen Castrén sai oman alkuperäisen suunnitelmansa mukaisesti painattaa teoksensa itse Simeliuksen lesken kirjapainossa, jossa myös seura painatti omia julkaisujaan. Painatuskustannuksiin Castrén sai avustusta sekä seuralta että sedältään Matthias Castrénilta, edelliseltä 140 ruplaa ja jälkimmäiseltä peräti 400 ruplaa (Estlander 1928: 45). Näihin aikoihin Matias Aleksanteri oli itse aivan varaton ja korviaan myöten veloissa. Huhtikuussa 1841 Jakov Grot päivitteli Castrénin taloudellista tilannetta kirjeessä ystävälleen, Pietarin yliopiston venäjän kielen ja kirjallisuuden professorille P. Pletnjoville, joka ihmetteli Castrénin velkoja ja arveli tämän omasta syystään vajonneen kaupunkielämän houkutuksissa niin surkeaan tilanteeseen. Grot kuitenkin korosti, että Castrén vietti hyvin askeettista elämää suomatta itselleen mitään ylimääräisiä nautintoja. (Groundstroem [toim.] 1912: 188, 191, 193.)

Kesäkuun lopussa Castrén luopui Suomalaisen Kirjallisuuden Seuran sihteerin tehtävistä, ja Kalevalan ruotsinnos ilmestyi painosta. Kalevalaa selittäessään Castrén oli vakuuttunut siitä, että teokseen olisi ehdottomasti liitettävä selitys- ja kommenttiosa, ja tämän tarpeellisuutta korostettiin myös käännöksen lehtiarvostelussa, johon palataan jäljempänä. Castrén ryhtyikin laatimaan käsikirjoitusta "Ordförklaringar m. fl. anmärkningar", joka oli tarkoitus julkaista uudessa Suomi-aikakauskirjassa (Fennica 2019: 481), mutta tämä jäi keskeneräiseksi.

Pietarista ei vieläkään kuulunut kaivattua viestiä retkikuntahankkeen edistymisestä. Syksyllä oli joka tapauksessa luvassa uusi matka, sillä Elias Lönnrot oli kutsunut nuoremman kollegansa yhteiselle Lappiin suuntautuvalle tutkimusmatkalle. Mikä parasta, Lönnrot lupasi maksaa suurimman osan matkakustannuksista. Marraskuussa miehet kohtasivat Kemissä ja yhteinen matka kohti Lappia alkoi. Siltä ei Castrén enää palannutkaan suoraan etelään, sillä vuoden 1842 alussa hän sai Inarin pappilaan kirjeen, jonka mukaan Pietarissa asiat olivat edistyneet ja kauan odotettu tutkimusmatka näyttäisi viimeinkin toteutuvan. Sjögren kehotti Castrénia hakemaan 
kotimaastaan valtionavustusta, jotta voisi matkustaa samojedialueitten kautta itään ja lopulta Siperiaan, josta alkaisi Pietarin Tiedeakatemian rahoittama tutkimusmatkan osuus. Castrénille myönnettiinkin matkaansa varten 1000 hopearuplan suuruinen avustus (Helsingfors' Morgonblad 27.10.1842). Lönnrot ja Castrén matkasivat Arkangeliin, jossa he erosivat kesäkuussa 1842. Lönnrot lähti kohti Aunuksen kuvernementtiä, Castrén vietti loppukesän ja syksyn Arkangelissa opiskellen nenetsiä ja suuntasi sitten Sjögrenin jälkiä seuraten itään.

\section{Millainen Kalevalan käännöksestä tuli}

Kalevalan ruotsinnoksen arvioijat ovat hyvin yksimielisesti todenneet, että käännös on yksinkertainen, selvä ja alkuteoksen sisältöä uskollisesti noudattava. Castrén itse sanoo käännöksensä esipuheessa, että tarkkuuden ja taiteellisen vaikutelman joutuessa ristiriitaan on etusija yleensä annettu sointuvalle kieliasulle, mutta käytännössä asia näyttää olevan juuri toisin päin. Yleensä Castrén onnistuu välittämään säkeiden perusmerkityksen lukijalle selvemmin kuin lähtöteksti konsanaan, mutta erityisiä kaunokirjallisia ansioita hänen käännöksessään ei ole.

Kääntäessään Kalevalaa Castrén muutti julkaisun rakennetta sillä tavoin, että hän laati esipuheeseensa yhtenäisen, runojen järjestystä noudattelevan selostuksen eepoksen sisällöstä. Lönnrotilla kunkin runon sisältöä oli selostettu runon alussa olevassa suorasanaisessa summaariossa, ja samoin oli tehnyt Keckman julkaisematta jääneessä suorasanaisessa käännöksessään. Lönnrotin esikuvasta Castrén poikkesi myös siinä suhteessa, ettei hän numeroinut runojen säkeitä. Tavallaan tämä on ymmärrettävää, sillä käytännössä numerointi ei olisi tarkalleen noudattanut alkuteosta, ja tästä olisi varmasti koitunut sekaannuksia Kalevalaan viitattaessa. Castrén saattoi joskus vaihtaa säkeiden järjestystä, jättää toisintosäkeitä pois, jakaa alkuperäisen säkeen kahdeksi sisällön sitä vaatiessa, ja joissakin tapauksissa hän otti alkuperäisen säkeen tilalle Kalevalan loppuun painetuista toisinnoista löytämänsä paremman säkeen. Nämä hän merkitsi erikseen tähdellä ja hakasulkeilla käännökseensä. Kaikkein suurin ero alkuperäiseen on runon 25 alussa. Siltä kohtaa Castrén sensuroi kaikkiaan 106 säkeen laajuisen kuvauksen siitä, kuinka portto Pohjolan emäntä tuli raskaaksi ja valmistautui synnyttämään tauteja Väinölän väen piinaamiseksi. Myös muualta Castrén saattoi jättää liian arkaluontoisiksi arvioimiaan säkeitä pois.

Esipuheessa Castrén sanoo ottaneensa huomioon Kalevalan osien aiemmin julkaistut ruotsinnokset, mutta tämä ei tarkoita sitä, että hän olisi hyväksynyt ne sellaisinaan omaan käännökseensä. Ainoastaan Runebergin käännökset hän on kelpuuttanut jokseenkin muuttamattomina, kaikkiin muihin hän on tehnyt runsaasti korjauksia. Myös Lönnrotin ruotsinnoksia hän on muokannut kovalla kädellä. (Tarkemmin Fennica 2019, käännösten vertailut ja kommentit s. 52 alk.) Kalevalan kääntäjillä on monissa tapauksissa ollut eri näkemys siitä, mikä olisi tyyliltään paras ruotsalainen käännösvastine. Esimerkiksi usein toistuva säe Vaka vanha Väinämöinen on Keckmanilla Fasta gamle Wäinämöinen, Lönnrotilla Gamle värde Väinämöinen, 
Ingmanilla Gamle värde Väinämöinen tai Gamle ädle Väinämöinen ja Castrénilla Gamle trygge Väinämöinen. Nuoren naisen hellittelevä nimitys on alkuperäisessä eepoksessa kainaloinen kana, jonka vastine Keckmanin mukaan on när dig varande höna älskling, mutta Runeberg ja Castrén ovat vaihtaneet lajia ja korvanneet kanan sanalla dufva 'kyyhky'. Myös hellittelevä käkönen on muuttunut dufvaksi Castrénin käännöksessä.

Kalevalan kerronnassa preesens ja imperfekti vaihtelevat, usein niin, että aktiiviset toimet ja nopeasti etenevät tapahtumat kerrotaan imperfektissä, mutta pitkäkestoisemman tai dramatisoidun tilanteen kuvauksessa käytetään preesensiä. Castrén ei aina ole valinnut alkutekstin mukaista aikamuotoa, esimerkiksi kolmitavuisen imperfektin hän on saattanut korvata kaksitavuisella preesensmuodolla, jos se on runomitan kannalta ollut sopivampi ratkaisu.

Castrén ei ole kääntänyt Kalevalan tekstiin sisältyviä erisnimiä, vaan on siirtänyt ne käytännöllisesti katsoen sellaisinaan ruotsinkieliseen tekstiin. Joissakin tapauksissa hän on lyhentänyt tai muulla tavoin muokannut nimeä saadakseen sen sopimaan paremmin runomittaan. Esimerkiksi Annikista on tullut Anni ja Sariolasta Sarjo-sundet. Monilla Kalevalan nimillä on kuitenkin myös appellatiivinen merkitys, ja nimet luovat mielikuvaa henkilön, olennon tai paikan luonteesta tai ulkonäöstä (esim. Kalma, Kivutar, Pimentola, Piru, Pohjola, Puhuri, Seppo, Ukko). Näin ollen suomea osaava lukija saa Castrénin käännöksestä irti paljon enemmän kuin sellainen, jolle erisnimet ovat täysin läpinäkymättömiä.

Castrén ei aina ole Lönnrotin kanssa samaa mieltä siitä, mikä on erisnimi ja mikä yleisnimi. Molemmat ovat tosin kirjoittaneet kaikkien säkeiden alut isolla kirjaimella, joten alkuun sattuvien nimien tulkinnasta ei alkukirjaimen perusteella voi sanoa mitään. Säkeen sisällä erot kuitenkin näkyvät. Esimerkiksi Lönnrotin on voinut kirjoittaa jumalan ja luojan pienellä kirjaimella tähdentääkseen, että on kysymys esikristillisen ajan hahmoista, sen sijaan Castrén on vastaavissa kohdissa käyttänyt isoa kirjainta. Sampo on Castrénin tekstissä erisnimi, mutta Lönnrot on kirjoittanut sen pienellä alkukirjaimella.

Myös jonkin verran runomittaa koskevia ongelmia on syntynyt suomenkielisten erisnimien esiintymisestä ruotsinkielisessä runossa. Etenkin pitkiä nimiä on ollut vaikea sijoittaa säkeisiin. Niiden kohdalla Castrén ei näytä pitäneen kiinni säännöstä, jonka mukaan normaalitrokeisen säkeen keskellä on tauko eli kesuura, eikä myöskään viskurilaista, jonka mukaan pitkät sanat pyritään sijoittamaan säkeen loppuun (Ut till Kalevalas skogmark). Painosuhteetkaan eivät aina satu kohdalleen, jos nimiä painotetaan suomalaiseen tapaan.

Vaikka Castrénilla on sisällön tulkinnassa epäilemättä ollut hyötyä Keckmanin Kalevala-aineistoista, tekstin saattamisessa runomuotoon niistä ei ole ollut mitään apua. Keckmanin käännökseen sisältyy kyllä runomuotoisiakin säkeitä, mutta nämä ovat usein helppoja tapauksia, joissa sanasta sanaan käännetty vaihtoehto sattuu sopimaan myös kalevalamittaan (esim. Sanoi vanha Väinämöinen - Sade gamle Väinämöinen). Vaikka varsinkin Keckmanin käännöksen loppupuolelta löytyy myös runomuotoisia osuuksia, mittaan pyrkiminen ei selvästikään ole ollut hänen 
varsinaisena tavoitteenaan, vaan se on ollut sisällön mahdollisimman tarkka toistaminen (ks. myös Pääkkönen 2005: 85-90). Tästä esimerkiksi voidaan ottaa eepoksen ensimmäiset säkeet Mieleni minun tekevi jne.:

\section{Keckman}

Lust göres mig

Min hjärna tänker

Lust (har jag) att börja (ihop) med runor

Laga mig att sjunga.

\section{Castrén}

Nu mig göres lust $\mathrm{i}$ hågen,

I mitt hufvud bor en tanke,

Lust jag har att börja runor,

Laga mig till reds att sjunga.

Koska suomi ja ruotsi ovat tavurakenteeltaan erilaisia kieliä, Castrén ei ole voinut käyttää ruotsinnoksessaan täsmälleen samanlaista mittaa kuin on alkuperäisissä runoissa (mitasta esim. Kaukonen 1979: 72-77). Castrénin säkeet ovat trokeemittaisia ja sisältävät melkein aina kahdeksan tavua, niin kuin asiaan kuuluu (poikkeuksia Från ${ }^{5}$ granens gyllne krona; Invid horn-borgens tinnar), mutta silloin tällöin Castrén on joutunut sijoittamaan yksitavuisia sanoja säkeen loppuun (Alltför öfvermodig blir du; Icke hammare, ej skaft ens), pitkiä painollisia ensitavuja runotahdin laskuun sekä pitkävokaalisena ääntyviä tavuja säkeen loppuun, mikä oikeaoppisessa kalevalamitassa ei olisi mahdollista.

\section{Lönnrot}

Louhi Pohjolan emäntä,

Pohjan akka harwahammas,

Nousi aiwan aikasehen,

Aiwan aika huomenessa;

\section{Castrén}

Louhi Pohjolas värdinna,

Pohja-gårds tandglesa gumma

Vaknade en morgon tidigt

Och i dagens gryning uppsteg.

Sanojen ensitavut eivät välttämättä ole ruotsissa pääpainollisia kuten suomessa, ja vokaalin pituus riippuu tavun laadusta, joten tavun pituuden ja painollisuuden suhde ei edes periaatteessa voi olla ruotsinnoksessa samanlainen kuin Lönnrotin Kalevalan runoissa. Normaalitrokeisen säkeen keskellä on Castrénilla usein kesuura, mutta ei välttämättä aina. Runojen rytmi on Castrénilla monotonisempi kuin Lönnrotin Kalevalassa, sillä varsinaisia murrelmasäkeitä hän ei juuri viljele. Joukossa on kyllä säkeitä, jotka kirjoitettuina näyttävät murrelmasäkeiltä, mutta kun ne lukee ääneen ja painottaa idiomaattiseen tapaan, ne muuttuvat normaalitrokeeksi (esim. Börja samtal med varandra; Louhi Pohjolas värdinna). Murrelmasäkeiksi voidaan ehkä laskea sentapaiset esimerkit kuin Läser ursprungsord grundenligt ja Hjelp ifrån grundämnens modrar, joskaan näissä runotahdin laskuun sattuva pääpainollinen tavu ei ole samassa mielessä lyhyt kuin suomenkielisessä mitassa edellytetään. Sitä paitsi grundenligt-sanaa ei ruotsissa oikeastaan olekaan, vaan se on ilmeisesti Castrénin

5. Tämä on ilmeisesti painovirhe, sillä hieman jäljempänä säe toistuu mitaltaan korrektina, kun Från-sanan paikalla on Ifrån. 
tilapäismuodoste. Alkusoinnusta Castrén on tietoisesti tinkinyt enemmän kuin Lönnrot omissa ruotsinnoksissaan, sillä hänen mielestään se ei ollut ruotsille ominainen tyylikeino.

Jokin verran häiritseviä ovat säkeenylitykset, joissa Castrén ei ole pystynyt sisällyttämään keskenään läheisesti yhteen kuuluvia sanoja samaan säkeeseen. Säkeen raja voi sattua esimerkiksi määritteen ja pääsanan välille (Hur betalar jag min moders / Mjölk, och hur min faders godhet?), ja joskus predikaatti jää muusta ydinlauseesta irralleen seuraavan säkeen alkuun (Skaftets längd femhundra alnar / Var, och pinnarnas etthundra). Lisää esimerkkejä löytyy heti ensimmäisestä runosta:

\section{Lönnrot}

Weli kulta weikkoseni,

Kaunis kielikumppalini!

Harwoin yhtehen yhymmä,

Saanemma sanelemahan,

Noita saatuja sanoja,

Wirsiä wetelemiä,

Wyöltä wanhan Wäinämöisen,

\section{Castrén}

Du min vän, min gode broder,

Ädle språk-kamrat, ej ofta

Händer, att vi här förenas,

Börja samtal med varandra,

Dessa ord som gåfva fångna,

Dessa ljufva sånger, tagna

Från den gamle Wäinös bälte.

\section{Käännöksen vastaanotto ja vaikutus}

Kalevalaa ja sen kokoajaa Elias Lönnrotia oli juhlittu yliopistopiireissä jo heti eepoksen ilmestymisestä lähtien, mutta vasta Kalevalan ruotsinkielinen käännös ja Castrénin luennot Kalevalasta tekivät eepoksen koko sisällön käytännössä tutuksi suurelle yleisölle (G. Castrén 1945: 22-23). Castrénin esipuheeseen kirjoittaman sisältökuvauksen perusteella sai melko kattavan käsityksen eepoksen sisällöstä runoja lukemattakin. Lisäksi esipuhe muovasi yleistä käsitystä eepoksen luonteesta. Castrén korosti sisällön aitoutta: koko eepoksessa ei ollut yhtään ainoaa tohtori Lönnrotin sepittämää säettä, vaan kaikki oli suoraan kansan suusta. Myöhempi tutkimus on osoittanut tämän väitteen paikkansa pitämättömäksi. Esimerkiksi Väinö Kaukosen analyysin mukaan Kalevalan ensimmäisen painoksen eli ns. Vanhan Kalevalan runosäkeistä $33 \%$ on alkuperäisiä kansanrunon säkeitä, $50 \%$ tavalla tai toisella muokattuja, $14 \%$ kansanomaisista aineksista muodostettuja mutta runoissa esiintymättömiä ja $3 \%$ Lönnrotin sepittämiä tai toistaiseksi tuntemattomasta lähteestä saatuja (Kaukonen 1945: 523; uusimmasta tutkimuksesta ks. Avoin Kalevala). Joka tapauksessa Castrénin käsitys runojen aidosta kansanomaisuudesta on aikoinaan vaikuttanut suuresti Kalevalaa koskevaan yleiseen mielipiteeseen.

Käännöksen ilmestyttyä Helsingfors' Morgonblad (47, 48, 53/1841) julkaisi teoksesta laajan arvostelun. Arvostelijan nimeä ei mainittu, mutta se oli aivan ilmeisesti lehden uusi toimittaja Fabian Collan, joka jo aiemminkin oli puheissaan 
ja kirjoituksissaan useasti käsitellyt Kalevalaan ja kansanrunouteen liittyviä kysymyksiä. Osakunta-aktivistina tunnettu Collan oli papin poika Iisalmesta, ja hän oli yksi niitä harvoja, jotka alusta pitäen todella pystyivät lukemaan ja ymmärtämään kalevalaista runokieltä. Arvostelunsa alussa hän totesi, että toistaiseksi Kalevala oli ollut hermeettisesti suljettu aarre, kunnes Castrén oli ryhtynyt kääntämään sitä kaksi vuotta sitten - siis 1839 - Suomalaisen Kirjallisuuden Seuran kehotuksesta.

Collan totesi, samaan tapaan kuin Castrén esipuheessaan, ruotsin ja suomen kielen rakenteen ja kirjallisen kehitysasteen erot, jotka olivat vaikeuttaneet kääntämistä. Varsinkin loitsuissa käännösvastineiden löytäminen oli ollut hankalaa, koska ruotsista puuttuivat vastaavat kulttuurisidonnaiset käsitteet ja sanat. Sen sijaan eeppiset ja jopa lyyrisetkin osuudet sopivat ruotsin kielen luonteeseen paremmin. Esimerkiksi Väinämöisen soiton kuvausta Collan piti erityisen onnistuneena, samoin sammon ryöstöä ja Pohjolan häistä kertovaa osuutta. Käännösnäytteenä Collan julkaisi 22. runon loppuosan, joka sisälsi kuvauksen Väinämöisen tenhoisasta soitosta.

Myönteiseen henkeen kirjoitetun alkuosan jälkeen Collan käsitteli käännöksen heikkouksia. Hän osoitti muutamia väärin tulkittuja sananmuotoja ja ruotsalaisen kieliasun ongelmia etenkin prepositioiden käytössä, epäonnistuneita sananvalintoja ja joitakin selviä lipsahduksia. Käännöksessä oli myös kohtia, joissa ei ollut varsinaista virhettä, mutta ne poikkesivat idiomaattisesta ruotsalaisesta esitystavasta ja olivat yleisesti outoja tai sitten selviä fennismejä. Joissakin harvoissa kohdin käännöksen ymmärtäminen oli mahdotonta vertaamatta alkuperäiseen tekstiin. Collan kuitenkin korosti, että virheiden määrä oli koko teoksen laajuutta ajatellen pieni.

Lopuksi Collan ylisti teoksen esipuhetta. Se oli sekä kiinnostava että hyödyllinen johdatus Kalevalan maailmaan. Tosin Collan olisi toivonut vieläkin yksityiskohtaisempaa käsittelyä ja erityispiirteiden avaamista. Lukemista vaikeuttavana tekijänä hän mainitsi selittävien alaviitteiden puuttumisen ja toivoi, että Castrén jatkossa täydentäisi käännöstään tällaisella kommentaarilla. Castrénin postuumeista käsikirjoituksista onkin nähtävissä, että hän todella aikoi laatia myös Collanin toivomat selitykset, mutta tämä työ ei ehtinyt valmistua julkaisukuntoon (tarkemmin Fennica 2019: 481).

Castrénin käännöksen ilmestyminen oli tyrmäävä isku Juvan kappalaiselle Abraham Poppiukselle, joka kaikessa hiljaisuudessa muiden tietämättä oli työstänyt omaa ruotsinnostaan. Poppius oli aikoinaan ollut A. J. Sjögrenin ja Carl Axel Gottlundin ystävä ja yhteistyökumppani, ja häntä oli vanhan Turun Akatemian loppuaikoina pidetty lupaavana runoilijana, itämurteiden taitajana ja yhtenä murteiden taistelun aloittajana. Hän oli jo vuonna 1818 kirjoittanut tutkimuksen suomen itämurteiden refleksiivimuodoista, siis samasta aihepiiristä, josta myös Carl Niclas Keckman kirjoitti myöhemmin virkaväitöskirjansa, ja Uppsalassa opiskellessaan hän oli avustanut saksalaista Hans Rudolf Schröteriä, kun tämä julkaisi saksannoksen valikoimasta suomalaista kansanrunoutta (Schröter 1819). Myöhemmin Poppius oli kuitenkin lähtenyt papin uralle ja irtautunut kansallisromanttisten kieliaktivistien piiristä. (Poppiuksen elämäkerrasta esim. Anttila 1932.) Poppius perehtyi Castrénin käännökseen, totesi sen selvästi omaansa paremmaksi ja päätti luopua omista 
julkaisuaikeistaan. Hän antoi käyttää käsikirjoituksen lehtiä oman työhuoneensa seinäpaperina ja maalata tekstin näkymättömiin. (Ett manuskripts öde 1869.)

Vuonna 1845 ilmestyi kansallishenkinen kirjallisuusjulkaisu Fosterländskt Album, jonka olivat toimittaneet Herman Kellgren, K. K. Tigerstedt ja Robert Tengström. Muun aineiston ohella siihen sisältyi joukko Kalevalan runoja, jotka olivat peräisin Castrénin ruotsinnoksesta. Kolmiosaisen albumin ensimmäisessä niteessä oli joukko virolaisia ja suomalaisia kansanrunoja sekä muutamia kirjallisuutta käsitteleviä kirjoituksia. Niteen loppuun Tengström kirjoitti Kalevalaa koskevan esseen. Sen ensimmäisellä sivulla (alaviitteessä) hän totesi, että Lönnrotin merkittävät saavutukset muinaisrunojen löytämisessä ja muistiin merkitsemisessä olivat yleisesti tunnetut, mutta nyt hän opasti lisätietoa kaipaavia lukijoita tarttumaan Castrénin ruotsinnoksen esipuheeseen ja perehtymään sen avulla kootusti Kalevalaa koskeviin yleisiin käsityksiin (Tengström 1845: 123). Tengströmin oma osuus sisältää hämmästyttävän syvällistä pohdintaa Kalevalan runojen luonteesta ja tulkinnasta ottaen huomioon, että Tengström oli tähän aikaan vain 23-vuotias nuorukainen. Paljon vanhemmaksi hän ei elänytkään, sillä hän kuoli lavantautiin Pariisissa jo vuonna 1847. Hän ei siis ehtinyt nähdä, kuinka Castrén lokakuussa 1850 meni naimisiin hänen pikkusiskonsa Natalian kanssa ja antoi vuonna 1851 syntyneelle pojalleen nimeksi Robert.

Kalevalan maine kantautui myös ulkomaille. Historiallis-vertailevan kielentutkimuksen kärkinimiin kuulunut Jacob Grimm piti Kalevalaa käsittelevän esitelmän Berliinin tiedeakatemiassa 13.3.1845. Grimm lähetti esitelmänsä Elias Lönnrotille, ja se julkaistiin ruotsiksi käännettynä Fosterländskt Albumin toisessa niteessä. Esitelmässään Grimm (1845: 64) kertoo perehtyneensä Kalevalaan Castrénin erinomaisen käännöksen avulla, ja samassa kohtaa hän toteaa, että Castrénilla näyttää muutenkin olevan hyvin perusteelliset tiedot suomesta ja sen sukukielistä. Toisaalla (mts. 68) hän viittaa Castrénin julkaiseman syrjäänin (komin) kieliopin sisältöön. Grimmin pitkä esitelmä sisältää runsaasti yksityiskohtaista pohdintaa Kalevalan eri osista sekä runonäytteitä, osittain saksaksi käännettyinä, mikä kertoo aidosta kiinnostuksesta suomalaista eeposta kohtaan.

Eepoksen ilmestyminen oli tehnyt Elias Lönnrotista kysytyn asiantuntijan, mutta kaikkeen hän ei ehtinyt tai halunnut lähteä mukaan. Niinpä hän pitkään epäröityään vastasi kieltävästi saksalaiselle professorille Hermann Brockhausille, joka halusi Lönnrotin henkilökohtaiseksi suomen kielen opettajakseen Leipzigiin voidakseen itse lukea Kalevalaa alkukielellä ja kääntääkseen sen saksaksi (Anttila 1935: 6-7). Lönnrotin asemesta Brockhausin luo lähetettiin Herman Kellgren, joka oli Fabian Collanin lapsuudenystävä, syntyperäinen suomen kielen puhuja ja kuunnellut Castrénin luentoja Kalevalasta. Kellgren lähti matkaan varustettuna Lönnrotin ja Castrénin kieliopillisilla käsikirjoituksilla sekä Castrénin luennoilta tehdyillä muistiinpanoilla. Lisäksi hänellä oli kopio Keckmanin Kalevala-muistiinpanoista (G. Castrén 1945: 198).

Herman Kellgrenin arvion mukaan Grimmin esitelmä ja sen ylistävät sanat Castrénin ruotsinnoksesta saattoivat houkutella kääntämään Kalevalaa saksaksi nimenomaan Castrénin ruotsalaisesta käännöksestä. Hän kuitenkin uskoi vakaasti, 
että Brockhausin suoraan alkukielestä tekemä käännös valmistuisi seuraavana vuonna [1847], sillä tulevasta teoksesta oli määrä ilmoittaa lehdessä jo muutaman kuukauden kuluessa (G. Castrén 1945: 196). Brockhausin työ jäi kuitenkin kesken, eikä Vanha Kalevala ehtinyt ilmestyä kenenkään muunkaan saksantamana. Jo vuonna 1849 Lönnrot julkaisi eepoksen uuden, 50 runon laajuisen laitoksen, ja sen käänsi saksaksi Anton Schiefner, joka hieman myöhemmin toimitti julkisuuteen myös valtaosan Castrénin tieteellisestä jäämistöstä saksan kielellä.

\section{Mitä Kalevalan ruotsinnos merkitsi Castrénille}

Edellä on käynyt ilmi, että Kalevalan merkitys Castrénin uravalinnassa ja tieteellisessä työskentelyssä oli monin tavoin olennainen. Castrén palasi Kalevalaa koskeviin kysymyksiin useaan otteeseen vielä senkin jälkeen, kun hän oli päässyt kauan kaipaamilleen tutkimusmatkoille ja julkaissut kielioppeja ja muita tutkimuksia suomalais-ugrilaisten, samojedilaisten ja muiden Siperian kielten alalta. Hän otti kriittisesti kantaa Kalevalan uuteen, 50 runoa sisältävään laitokseen, joka ilmestyi vuonna 1849 ja johon sisältyi monien eri kerääjien runoaineksia. Hän luennoi Uudesta Kalevalasta syksyllä 1851 tultuaan nimitetyksi suomen kielen ja kirjallisuuden professoriksi. Hän käsitteli Kalevalaa myös viimeisiksi jääneissä luennoissaan, joiden varsinaisena aiheena oli suomensukuisten kansojen mytologia.

Kalevalan ruotsinnoksella oli oma tärkeä roolinsa Castrénin tieteellisellä uralla. Jo se seikka, että ruotsinkielistä käännöstä oli turhaan odotettu ja toivottu monen vuoden ajan, lisäsi kiinnostusta ja innostusta Castrénin käännöstä kohtaan, kun se lopulta ilmestyi. Kalevalan sanaston ja runokielen vaikeaselkoisuus oli yleisesti tiedossa, ja tästä syystä kääntäjä ja hänen kielitaitonsa saivat osakseen erityistä arvostusta. Aivan ilmeisesti Kalevalan ruotsinnos herätti laajempaa huomiota kuin Castrénin vuonna 1839 ilmestynyt väitöskirja, jota luettiin lähinnä tutkijapiireissä.

Kalevalan myötä Castrénin nimi tuli yleisesti tunnetuksi sekä Suomessa että ulkomailla. Kirjojen kääntäminen oli 1800-luvulla varsin tavallista, ja enimmäkseen se katsottiin pelkäksi rutiinityöksi, joka sopi opiskelijoille ja muille tilapäistöiden tekijöille. Kääntäjien nimiä ei useinkaan edes ilmoitettu julkaisujen yhteydessä. Kalevala oli erityistapaus, ja sen kääntäminen oli poikkeuksellisia kykyjä vaativa suoritus.

Kalevalan painattaminen merkitsi kustannuksia, mutta niiden kattamiseen Castrén onnistui saamaan tukijoita. Lopulta hanke kääntyi myös tekijän taloudelliseksi voitoksi. Kalevalan jälkeen Castrénin oli helpompi saada yhteistyökumppaneita, tukijoita ja rahoitusta siihen työhön, jota hän itse piti kaikkein tärkeimpänä: tutkimusmatkoihin ja kielioppien tekoon. Castrén oli ollut aivan oikeassa arvellessaan vuonna 1840 ystävälleen Ehrströmille, että kirjojen avulla voisi sopivasti "nykäistä" pietarilaisia ja vähän muitakin.

Kalevalan käännöksen pohjalta Castrén pääsi osallistumaan vilkkaaseen keskusteluun, joka koski eepoksen luonnetta ja tulkintaa. Osa puheenvuoroista käytettiin 
osakunnissa, mutta osa julkaistiin sanomalehdissä tai laajemmalle yleisölle suunnatuissa kirjallisissa albumeissa, joten keskustelua oli mahdollisuus käydä ja seurata myös akateemisten piirien ulkopuolella. Näitä keskusteluja on myöhemmässä tutkimuksessa referoitu seikkaperäisesti, ja erityistä huomiota on saanut osakseen Robert Tengströmin teoreettispohjainen tarkastelutapa. Jo vuotta ennen edellä mainittua Fosterländskt Albumin esseetä hän oli tutkinut Pohjalaisen osakunnan kausijulkaisussa Joukahaisessa, miten Suomen kansaa kuvattiin Kalevalassa. Hän näki Kalevalan monitasoisena heijastumana kansakunnan kehityshistoriasta, jossa alkuperäisistä yhteyksistään irronneet tarinat olivat muodostaneet kansan kollektiivisessa muistissa uuden kertomuksen. (Keskusteluista tarkemmin esim. Karkama 2008: 145-157.) Castrén käytti Lönnrotin Kalevalaa omien tutkimustensa lähdeaineistona ja pohti historiallisen ja mytologisen tulkinnan suhdetta, mutta moitti eeposrakennelmaa epäyhtenäiseksi ja osittain epäloogiseksi. Hänen tärkein ansionsa Kalevalakeskustelussa oli joka tapauksessa se, että hän oli tehnyt se ylipäänsä mahdolliseksi. Ruotsinkielistä käännöstä pystyi helposti lukemaan koko sivistyneistö, alkuperäistä suomenkielistä eeposta vain muutama harva.

Castrénin ruotsinnoksen vaikutus olisi voinut olla suurempikin, jos Kalevalasta ei olisi niin pian ilmestynyt uutta, laajennettua laitosta. Sen valmistuttua Castrénin käännös menetti suuren osan käyttöarvostaan. Vaikka versioissa oli runsaasti yhteistäkin ainesta, kokonaisuus oli kuitenkin niin erilainen, että uusi käännös oli ehdottomasti tarpeen. Sen laati Fabian Collanin nuorempi veli Karl Collan, joka tunnetaan myös säveltäjänä, runoilijana ja kansansävelmien kerääjänä.

Nykyään Castrén tunnetaan nimenomaan kielentutkijana ja tutkimusmatkailijana, ei kääntäjänä, kaunokirjallisuudesta puhumattakaan. Edellä esitetty runo Emmalle on tiettävästi hänen ainoa oma kaunokirjallinen teoksensa. Kääntäjänäkään hän ei enää pitkiin aikoihin ole ollut ajankohtainen, ja hänen ruotsintamansa Kalevalan alkuperäiskappaleet ovat hautautuneet kirjastojen kätköihin. Useimmat nykysuomalaiset tarttuvat vastahakoisesti ruotsinkieliseen kirjallisuuteen, eikä erityisesti Kalevalan tapauksessa siihen ole tunnettu tarvettakaan, koska alkuteos on suomenkielinen ja sanakirjoja ja muita selitysteoksia on nykyään runsaasti saatavilla. Uusi tekniikka on kuitenkin tuonut myös Castrénin ruotsinkielisen Kalevalan jokaisen tietokoneen käyttäjän ulottuville. Sen digitoituja kappaleita on helppo löytää ja lukea verkosta. Castrénin käännöksen vertaileminen Kalevalan alkuperäiseen tekstiin ja Castrénin Kalevalaa koskevat muistiinpanot avaavat eeposta uudella tavalla, ja niistä heijastuvat käännösprosessin yksityiskohdat kertovat havainnollisesti siitä, millaisten vaikeuksien parissa suomen kielen tutkijat ja harrastajat kamppailivat aikana, jolloin tutkimusala oli vasta muotoutumassa eikä tueksi kelpaavaa tutkimustietoa juurikaan ollut käytettävissä. 


\section{Lähteet ja kirjallisuus}

\section{Arkistolähteet}

$\mathrm{KK}=$ Kansalliskirjasto. Helsinki.

Coll. 539 M.A. Castrénin kokoelma. Tieteellisiä muistiinpanoja. Fennica 1.

SKS $=$ Suomalaisen Kirjallisuuden Seura. Helsinki.

Carl Niclas Keckmanin (1793-1838) käsikirjoituksia.

Lönnrotiana.

Pöytäkirjat 1838-1841.

\section{Painetut lähteet ja kirjallisuus}

Anttila, Aarne 1931: Elias Lönnrot. Elämä ja toiminta I. Helsinki: Suomalaisen Kirjallisuuden Seura.

A[nttila], A[arne] 1832: Poppius, Abraham. - Kansallinen elämäkerrasto IV: 385-386. Porvoo: Werner Söderström Osakeyhtiö.

Anttila, Aarne 1935: Elias Lönnrot. Elämä ja toiminta II. Helsinki: Suomalaisen Kirjallisuuden Seura.

Borg, Carl Gustaf 1853: Matthias Alexander Castrén. Helsingfors: Öhmanska Bokhandeln.

Borg, Carl Gustaf 1870: Förord. - Nordiska resor och forskningar VI: V-VII. Helsingfors.

Branch, Michael 2006: Herderin vaikutus Anders Johan Sjögreniin ja sen seuraukset. Herder, Suomi, Eurooppa: 312-355. Toimittaneet Sakari Ollitervo ja Kari Immonen. Suomalaisen Kirjallisuuden Seuran Toimituksia 1060. Helsinki.

Castrén, Gunnar 1945: Herman Kellgren. Ett bidrag till 1840- och 1850-talens kulturhistoria. Helsingfors: Svenska litteratursällskapet i Finland.

Castrén, M. A. 1837: Om Finnarnes trollkonst. - Helsingfors' Morgonblad 27, 28/1837.

Castrén, M. A. 1838: Allmän öfversigt af Finnarnes gudalära och magi under hedendomen. [Pohjalaisen osakunnan vuosijuhlassa pidetty esitelmä.] - Nordiska resor och forskningar VI: 14-32. Helsingfors 1870.

Castrén, Matthias Alexander 1839a: Kirje C. R. Ehrströmille 23.9.1839. - Virittäjä 1902: $105-107$.

Castrén, Matthias Alexander 1839b: Dissertatio academica de affinitate declinationum in lingua Fennica, Esthonica et Lapponica. Helsingforsiae: Typis Frenckellianis.

Castrén, M. A. 1840a: Redogörelse 26.9.1839. - Finlands Allmänna Tidning 82, 83/1840.

Castrén, Matthias Alexander 1840b: Kirje C. R. Ehrströmille 2.2.1840. - Virittäjä 1902: 107-108.

Castrén, Matthias Alexander 1841a: Om betydelsen af ordet Lapp. - Suomi 2/1841: 3-7.

Castrén, Matthias Alexander 1841b: Anmärkningar rörande några ljud i Finskan. - Suomi 2/1841: 7-16.

Castrén, Matthias Alexander 1841c: Kirje C. R. Ehrströmille 17.6.1841. - Virittäjä 1902: 108-109.

Castrén, Matthias Alexander 1841d: Kalevala. Förra och sednare delen. Helsingfors: Simelii enka.

Castrén, M. A. 1842: Några dagar i Lappland. - Calender till minne af Kejserliga Alexanders-Universitetets andra secularfest: 207-232. Helsingfors.

Castrén, M. A. 1870: Stycken af år 1841 om våren hållna föreläsningar öfver Kalevala. Nordiska resor och forskningar VI: 53-97. Helsingfors: G. W. Edlund. 
[Collan, Fabian] 1841: Kalevala, öfversatt af M. A. Castrén. - Helsingfors' Morgonblad 47, 48/1841.

Estlander, B. 1928: Mathias Alexander Castrén. Hans resor och forskningar. Helsingfors: Söderström \& C:o Förlagsaktiebolag.

Ett manuskripts öde. - Wiborgs Tidning 16/1869.

Fennica 2019 = Matthias Alexander Castrén: Fennica. Manuscripta Castreniana. Linguistica I. Edited by Kaisa Häkkinen. Helsinki: Suomalais-Ugrilainen Seura.

Fosterländskt Album I-II. Utgifvet af H. Kellgren \& R. Tengström \& K. Tigerstedt. Helsingfors: Öhman 1845.

Grimm, Jacob 1845: Om det Finska Epos. - Fosterländskt Album II: 60-103. Helsingfors.

[Grotenfelt, G.], 1886. Fr. M. Franzénin yrittämä käännös Kalevalasta v. 1837. - Suomi II:19: $81-86$.

Groundstroem, Walter [toim.] 1912: Utdrag ur J. Grots brevväxling med P. Pletnjov angående finska förhållanden vid medlet av 1800-talet. I. Skrifter utgivna av Svenska Litteratursällskapet i Finland. Helsingfors.

Hautala, Jouko 1954: Suomalainen kansanrunouden tutkimus. Suomalaisen Kirjallisuuden Seuran Toimituksia 244. Helsinki.

Havu, I. 1945: Lauantaiseura ja sen miehet. Helsinki: Otava.

Häkkinen, Kaisa 2019: M.A. Castrén and the Swedish translation of the Old Kalevala. - Fennica. Manuscripta Castreniana. Linguistica I. Helsinki: Suomalais-Ugrilainen Seura.

[Ingman, E.A.], 1836a. Tjugonionde Runon i Kalevala. - Helsingfors' Morgonblad 17/1836.

I[n]g[ma]n, [E. A.], 1836b: Femte Sången i Kalevala. - Helsingfors' Morgonblad 79, 80/1836.

I[ngman], A. W. 1871: Muistelmia suomalaisuuden suhteista ja seikoista. - Kirjallinen Киukauslehti 9: 218-227.

I[ngman], A. W. 1873: Suomalaisesta sanaseppäisyydestä. - Joukahainen VII: 142-159.

Joki, Aulis J. 1953: Johdannoksi. - M. A. Castrén. Tutkimusmatkoilla Pohjolassa. Helsinki: Tammi.

Kalevalan kulttuurihistoria. Toimittaneet Ulla Piela \& Seppo Knuuttila \& Pekka Laaksonen. Suomalaisen Kirjallisuuden Seuran Toimituksia 1179. Helsinki.

Karkama, Pertti 2008: Kalevala ja kansallisuusaate. - Kalevalan kulttuurihistoria: 124-169.

Kaukonen, Väinö 1945: Vanhan Kalevalan kokoonpano II. Suomalaisen Kirjallisuuden Seuran Toimituksia 213. Helsinki.

Kaukonen, Väinö 1979: Lönnrot ja Kalevala. Suomalaisen Kirjallisuuden Seuran Toimituksia 349. Helsinki.

Korhonen, Mikko 1986: Finno-Ugrian Language Studies in Finland 1828-1918. The History of Learning and Science in Finland 1828-1918, Vol. 11. Helsinki: Societas Scientiarum Fennica.

Lönnrot, Elias 1828-1831. Kantele taikka Suomen Kansan, sekä Vanhoja että Nykysempiä, Lauluja ja Runoja. I-IV. Helsinki: Wasenius.

Lönnrot, Elias 1835a: Nionde [recte: 11.] Runon i Kalevala. Helsingfors' Morgonblad 91, 92 , 93/1835.

Lönnrot, Elias 1835b: Kalewala taikka wanhoja Karjalan runoja Suomen kansan muinosista ajoista. Helsinki: Suomalaisen Kirjallisuuden Seura.

Molnár, Ferenc A. 1981: E. A. Ingmanin Kalevala-kappale Unkarin Tiedeakatemian kirjastossa. - Congressus Quintus Internationalis Fenno-Ugristarum, Pars VII: 383-390. Redegit Osmo Ikola. Turku: Suomen Kielen Seura.

Pihlajamaa, Lauri 2006: Anders Wilhelm Ingman. Elämä ja kirjallinen työ. Stockholm: Terttu Pihlajamaa Förlag. 
P[iponiu]s, [Henrik] 1839: Öfversigt af Kalevala. - Spanska Flugan, sectio antepaenultima: $28-42$.

Pääkkönen, Irmeli 1994: Suomalainen sydämestä. Carl Niclas Keckmanin toiminta suomen kielen kehittäjänä. Suomi 172. Helsinki: Suomalaisen Kirjallisuuden Seura.

Pääkkönen, Irmeli 2005: Ahkeroimia. Piirteitä Carl Niclas Keckmanin elämäntyöstä. Suomen ja saamen kielen ja logopedian laitoksen julkaisuja 25. Oulu: Oulun yliopisto.

Rein, Th. 1928: Juhana Vilhelm Snellman. Edellinen osa. Helsinki: Otava.

[Runeberg, J. L.], 1836: Femtonde Runon i Kalevala. - Helsingfors' Morgonblad 47, 48, 49/1836.

[Runeberg, J. L.], 1837: Början af Kalevala. - Helsingfors' Morgonblad 30/1837.

R[uu]th, M[artti] 1927: Castrén, Mattias. - Kansallinen elämäkerrasto I: 387-388. Werner Söderström, Porvoo.

von Schröter, H. R. 1819: Finnische Runen, Finnisch und Deutsch. Upsala: Palmblad.

Snellman, J. V. 1870: M. A. Castréns lefnadsteckning. - Nordiska resor och forskningar VI: IX-LXXVIII. Helsingfors: G. W. Edlund. Saatavissa: <http://snellman.kootutteokset.fi/en/dokumentit/nordiska-resor-och-forskningar-6-osa-m-castr\% $\mathrm{C} 3 \% \mathrm{~A} 9$ nin$\mathrm{el} \% \mathrm{C} 3 \% \mathrm{~A} 4 \mathrm{~m} \% \mathrm{C} 3 \% \mathrm{~A} 4 \mathrm{kerta}>18.2 .2019$.

S[nellman], J. V. 1873: En gammal skola. - Joukahainen VII: 1-15.

Stipa, Günter Johannes 1990: Finnisch-ugrische Sprachforschung von der Renaissance bis zum Neupositivismus. Suomalais-Ugrilaisen Seuran Toimituksia 206. Helsinki.

Sulkunen, Irma 2004: Suomalaisen Kirjallisuuden Seura 1831-1892. Suomalaisen Kirjallisuuden Seuran Toimituksia 952. Helsinki.

Tengström, Robert 1845: Kalewala. - Fosterländskt Album I: 123-189. Helsingfors.

Topelius, Zachris 1822-1831: Suomen Kansan Vanhoja Runoja, ynnä myös Nykyisempiä Lauluja 1-5. Turku.

Waris, Heikki 1939: Savo-Karjalaisen Osakunnan historia I, 1833-1852. Porvoo - Helsinki: Werner Söderström Osakeyhtiö.

Årsberättelse 1939 = Årsberättelse, uppläst i Finska Litteratur-Sällskapet den 16 mars 1839. - Finlands Allmänna Tidning 81/1839.

\section{Internet-lähteet}

Avoin Kalevala. Suomalaisen Kirjallisuuden Seura. $<$ http://kalevala.finlit.fi/> 16.3.2019.

Finlands Allmänna Tidning. <https://digi.kansalliskirjasto.fi/sanomalehti/titles/1457-4314> 17.2.2019.

Helsingfors' Morgonblad. <https://digi.kansalliskirjasto.fi/sanomalehti/titles/1457-4365> 17.2.2019.

Hufvudstadsbladet. < https://digi.kansalliskirjasto.fi/sanomalehti/titles/0356-0724> 17.2.2019. SKVR = Suomen kansan vanhat runot. Suomalaisen Kirjallisuuden Seura. $<$ https://skvr.fi/>. Wiborgs Tidning. <https://digi.kansalliskirjasto.fi/sanomalehti/titles/1457-4853> 17.2.2019. Åbo Tidningar. $<$ https://digi.kansalliskirjasto.fi/sanomalehti/titles/1457-4802> 17.2.2019. 